Noordman, J., Weijden, T. van der, Dulmen, S. van. Communication-related behavior change techniques used in face-to-face lifestyle interventions in primary care: a systematic review of the literature. Patient Education and Counseling: 2012, 89(2), 227-244

\begin{tabular}{|l|l|}
$\begin{array}{l}\text { Postprint } \\
\text { Version }\end{array}$ & 1.0 \\
\hline Journal website & http://www.pec-journal.com/article/S0738-3991(12)00295-9/abstract \\
\hline Pubmed link & http://www.ncbi.nlm.nih.gov/pubmed/22878028 \\
\hline DOI & 10.1016/j.pec.2012.07.006
\end{tabular}

This is a NIVEL certified Post Print, more info at http://www.nivel.eu

\title{
Communication-related behavior change techniques used in face-to-face lifestyle interventions in primary care: A systematic review of the literature
}

\author{
JANNEKE NOORDMAN ${ }^{\text {A,* }}$, TRUDY VAN DER WEIJDEN ${ }^{\mathrm{B}}$, SANDRA VAN DULMEN ${ }^{\mathrm{A}, \mathrm{C,D}}$ \\ ${ }^{a}$ NIVEL, Netherlands Institute for Health Services Research, Utrecht, The Netherlands \\ ${ }^{\mathrm{b}}$ Maastricht University, School for Public Health and Primary Care (CAPHRI), Department of \\ General Practice, Maastricht, The Netherlands \\ ${ }^{c}$ Radboud University Nijmegen Medical Centre, Department of Primary and Community \\ Care, Nijmegen, The Netherlands \\ ${ }^{\mathrm{d}}$ Department of Health Science, Buskerud University College, Drammen, Norway
}

\begin{abstract}
A B S T R A C T
Objectives: To systematically review the literature on the relative effectiveness of face-to-face communication-related behavior change techniques (BCTs) provided in primary care by either physicians or nurses to intervene on patients' lifestyle behavior.

Methods: PubMed, EMBASE, PsychINFO, CINAHL and The Cochrane Library were searched for studies published before October 2010. Fifty studies were included and assessed on methodological quality. Results: Twenty-eight studies reported significantly favorable health outcomes following communica- tionrelated BCTs. In these studies, 'behavioral counseling' was most frequently used (15 times), followed by motivational interviewing (eight times), education and advice (both seven times). Physicians and nurses seem equally capable of providing face-to-face communication-related BCTs in primary care. Conclusion: Behavioral counseling, motivational interviewing, education and advice all seem effective communication-related BCTs. However, BCTs were also found in less successful studies. Furthermore, based on existing literature, one primary care profession does not seem better equipped than the other to provide face-to-face communication-related BCTs.

Practice implications: There is evidence that behavioral counseling, motivational interviewing, education and advice can be used as effective communication-related BCTs by physicians and nurses. However, further research is needed to examine the underlying working mechanisms of
\end{abstract}


Noordman, J., Weijden, T. van der, Dulmen, S. van. Communication-related behavior change techniques used in face-to-face lifestyle interventions in primary care: a systematic review of the literature. Patient Education and Counseling: 2012, 89(2), 227-244

communication-related BCTs, and whether they meet the requirements of patients and primary care providers.

\section{INTRODUCTION}

Patients' lifestyle behavior is significant for their physical and mental health. A healthy lifestyle (e.g. non smoking, minimal alcohol use, healthy diet and being physically active) can prevent or reduce the burden of chronic diseases such as type 2 diabetes, cardiovascular diseases, kidney diseases and chronic obstructive pulmonary disease (COPD) [1-3]. Regardless of the growing evidence of these preventive and therapeutic effects, the preva- lence of unhealthy lifestyle behaviors remains high. In the USA and many European countries the number of obese or overweight patients even increased in recent years [4] and tobacco dependen- cy and alcohol misuse continue to be major problems [5]. The high prevalence of unhealthy behaviors and chronic diseases has led to increased attention for a healthy lifestyle by governments around the world [6,7]. In the Netherlands for example, there is a renewed attention for the prevention of chronic diseases as stated in the prevention bill, aimed at reducing the incidence of smoking, alcohol abuse, obesity, type 2 diabetes and depression [8,9], by offering counseling to high risk patients in primary care. A general practitioner (GP) is the primary provider for patients at risk of developing lifestyle-related chronic illnesses. Interven- tions aimed at changing unhealthy lifestyles should therefore primarily take place in general practice [10]. In the UK, GPs have a contract since 1990 to promote health, which has encouraged a new structure of general practice, with practice nurses $(\mathrm{PN})$ and nurse practitioners (NP) working alongside GPs [11]. Within the Dutch general practice this collaborative system is also common since 1999 [12]. This enables GPs in the UK, the Netherlands and other Western countries to delegate tasks, regarding patients with chronic diseases and their lifestyle, to practice nurses and nurse practitioners or assistants $[12,13]$. Nowadays, a PN is employed in about $80 \%$ of the general practices in the Netherlands [14]. Dutch patients with chronic diseases visit the PN more often than the GP (from 2\% in 2003 to 39\% in 2008), while the total number of general practice visits remains stable [15].

Yet, changing lifestyle behavior is difficult and requires effort, time and motivation from both health care provider and patient. Besides, patients are often ambivalent about behavior change [16,17]. Providing advice about behavior change to patients is a common approach used by health care providers, although previous studies show that the effectiveness of advice giving is uncertain $[16,18]$. Insight into effective behavior change techni- ques (BCTs) can help health care providers in primary care to contribute to a better lifestyle and improved health for patients and eventually reduce health care costs $[17,19]$. Michie and colleagues [20] listed 137 BCTs that are used by health care providers in daily practice or can be used as an intervention to change behavior, such as goal setting, screening and motivational interviewing. So far, it is not clear which of these face-to-face communication-related BCTs are most effective in changing a patient's unhealthy lifestyle behavior and which provider is more effective in using these face-to-face communication-related BCTs. Many studies in the field of lifestyle interventions focus on one single aspect of behavior such as smoking [21,22] or physical activity [23,24]; included studies are often of low quality $[25,26]$ and interventions are seldom theory based [20]. Many studies into BCTs do appear to be inspired by 
Noordman, J., Weijden, T. van der, Dulmen, S. van. Communication-related behavior change techniques used in face-to-face lifestyle interventions in primary care: a systematic review of the literature. Patient Education and Counseling: 2012, 89(2), 227-244

theories, as for example Prochaska's and DiClemente's transtheoretical model, or Bandura's social cognitive theory [20].

Previous studies show that GPs and nurses (PN or NP) differ in their approach to patients and disease management; nurses spend more time on counseling patients than GPs and during the education and training of nurses there is more emphasis on patient education, lifestyle and disease prevention [27,29]. GPs, on the other hand, may traditionally be considered to have more authority to deliver care to patients. Nevertheless, several studies [27,30,31] suggest that care from GPs and nurses results in similar patient outcomes.

The current review study was set up to answer the following questions:

1. Which face-to-face communication-related behavior change techniques (BCTs) used in interventions are (most) effective for primary health care providers to intervene on patients' lifestyle behavior, i.e. smoking, alcohol, nutrition, weight and physical activity?

2. Which health care provider in primary care (physician or nurse) is more effective in using face-to-face communication-related BCTs?

\section{METHODS}

\subsection{Inclusion criteria}

A study was included in the review if (1) it concerned a randomized controlled trial (RCT) (2) the study was published in English, (3) the study population consisted of patients of 18 years or older, (4) the study focused on lifestyle communication about smoking behavior, alcohol use, nutrition intake (or diet/eating habits), weight or physical activity (exercise) and, in case of secondary prevention the following lifestyle related diseases: type II diabetes, COPD, asthma, cardiovascular disease, heart disease or kidney disease, (5) the population of professionals consisted of at least one health care provider (GP/physician, NP or PN) working within primary care, (6) the study included communication- related BCTs used in interventions by health care providers during individual face-to-face communication with the patient, (7) the study described outcomes on patient level regarding actual lifestyle behavior (self-reported or objective). 'Communication- related BCT' was defined as an interview technique delivered by one primary health care provider during face-toface communication with one patient. This technique is used to make patients aware of their lifestyle behavior and how to change or maintain this behavior. We included studies that aimed at primary prevention or/and secondary prevention following a diagnosis (see above criterion 4).

\subsection{Search strategy}

A computerized literature search was conducted to find studies that fulfilled all seven inclusion criteria. The following databases were searched in October 2010, without exclusions because of the date of publication or country: PubMed, EMBASE, PsychINFO, CINAHL and The Cochrane Library. Numerous keywords were used in combination in the search. The strategy was formulated in PubMed and adapted to the other databases (see Appendix A). From the selected search strategies; all references were extracted from the databases and imported in Reference Manager@); duplicates were removed. 
Noordman, J., Weijden, T. van der, Dulmen, S. van. Communication-related behavior change techniques used in face-to-face lifestyle interventions in primary care: a systematic review of the literature. Patient Education and Counseling: 2012, 89(2), 227-244

\subsection{Study selection}

A total of 4397 non-duplicate references were found (see Fig. 1 for flowchart of the inclusion procedure and excluded studies). The first selection for inclusion was performed by two reviewers (JN and SvD) based upon title and abstract. Both reviewers checked $50 \%$ of the imported references on title and abstract. Studies were included if they met the above mentioned seven inclusion criteria. This resulted in 323 references. Thereafter, both reviewers checked each other's included references. Agreement between reviewers was high (90\%). In case of doubt the full article was checked. In total 255 references were included after this first selection round.

In the second stage, the reviewers studied the full-text versions of the 255 articles to check the inclusion criteria. Six studies of the 255 could not be found in full text (neither in the Netherlands nor abroad). Ten percent of the 249 full text articles were studied by both reviewers (JN and SvD). Disagreements were resolved by discussion. Fifty-eight articles met all seven inclusion criteria and were therefore assessed on methodological quality. See Fig. 1 for information about the excluded studies.

\subsection{Quality assessment}

The methodological quality of the articles was assessed by two reviewers (JN and SvD) using the criteria list of the Cochrane Collaboration Back Review Group by Van Tulder et al. [32]. The list consists of the following 11 criteria (or questions) for internal validity (see Appendix B); (1) was the method of randomization adequate, (2) was the treatment allocation concealed, (3) were the groups similar at baseline regarding the most important prognostic indicators, (4) was the patient blinded to the intervention, (5) was the care provider blinded to the intervention, (6) was the outcome assessor blinded to the intervention, (7) were co-interventions avoided or similar, (8) was the compliance acceptable in all groups, (9) was the compliance acceptable in all groups, (10) was the timing of the outcome assessment in all groups similar, and (11) did the analysis include an intention-to-treat analysis.

Items could be scored as 'done', 'unclear' or 'not done'. All unclear scores were rated as 'not done'. Studies were considered of

'high quality' if at least five (instead of six) out of 11 criteria were scored as 'done'. This cut-off point is adjusted from Van Tulder et al. [32] and used because 'blinding' of health care providers in lifestyle interventions is often not (entirely) possible. Studies were considered of 'low quality' if they fulfilled less than five criteria. In case of doubt, the quality of the study was assessed after discussion between reviewers.

\subsection{Multiple studies from the same dataset}

We identified multiple articles from the same dataset, because these studies can cause a bias by affecting the results of the review more strongly [33]. Therefore, in line with previous research [34] we clustered studies from the same dataset together and referred to the first study (see Table 1 ).

\section{[FIGURE 1 [TABLE 2]}

\subsection{Data extraction}

Next, the following characteristics of each included study were described: 
Noordman, J., Weijden, T. van der, Dulmen, S. van. Communication-related behavior change techniques used in face-to-face lifestyle interventions in primary care: a systematic review of the literature. Patient Education and Counseling: 2012, 89(2), 227-244

1. (First) author, year of publication, country where the study was conducted.

2. Population/participants: number of patients, sex, age, primary/ secondary prevention, type of lifestyle behavior, number of health care providers and their profession.

3. Type of intervention(s).

4. Control group.

5. Study design.

6. If the intervention was based on a theoretical model.

7. Duration and frequency of the intervention(s).

8. Outcome measures and significant results.

9. Contribution of health care provider (GP/physician and/or nurse, alone or in combination with other health care providers).

Data were extracted from each article by two reviewers independently using a predefined data extraction form. These data were summarized in Tables 1 and 2 . Findings on outcome measures and significant effects for the effective studies are presented in Table 3.

\subsection{Data synthesis}

It was not possible to pool the data because of the different methods used to measure outcomes. Therefore, a ‘Best Evidence Synthesis’ was conducted based upon criteria developed by Van Tulder and colleagues [35] and adapted by Steultjens et al. [36]. This synthesis takes into account the design, quality and outcomes of studies. According to preset criteria (see Appendix C), the synthesis qualifies results from a sample of studies as 'evidence', 'moderate evidence', 'limited evidence', 'indicative findings' or 'no/ insufficient evidence'. At least one high quality RCT is necessary to establish some evidence for an intervention.

BCTs were considered as 'effective' if they provided enough evidence according to the 'Best Evidence Synthesis', taking into account the design (RCT), quality and significant positive outcomes of the studies.

\section{RESULTS}

In Table 1 an overview of the characteristics and quality of the 50 included studies (from 58 articles) is given.

\section{[TABLE 2]}

\subsection{Included studies}

\subsubsection{Study characteristics}

The publication year of the studies varied from 1991 [37] to 2010 [38-41]. Ten studies were carried out in the USA, eight studies in the UK, five in Australia, four in the Netherlands, in Denmark, and in Spain, three in New Zealand, Finland, and Italy, two in Canada and one in Thailand, Taiwan, Norway, and Sweden. 
Noordman, J., Weijden, T. van der, Dulmen, S. van. Communication-related behavior change techniques used in face-to-face lifestyle interventions in primary care: a systematic review of the literature. Patient Education and Counseling: 2012, 89(2), 227-244

\subsubsection{Methodology quality and design}

The methodology quality assessment yielded 37 high quality studies and 13 studies with lower quality. The following criteria were most often disobeyed: blinding, allocation concealment and intention-to-treat analysis. All studies described randomized trials, either with a control $(n=39)$ or a comparison $(n=11)$ group (Table 1).

\subsubsection{Population characteristics}

Twenty-five of the studies focused on a participant's single lifestyle behavior; ten on physical activity [42-51], six on smoking behavior [37,40,52-56], six studies on alcohol [39,41,57-60], two on nutrition [61-63] and one study on weight [64]. The other twenty-five reported on several lifestyle behaviors; one on physical activity and nutrition [65], two studies on nutrition and weight [66,67], three studies on physical activity and weight [68-71], three on nutrition, physical activity and weight [72-74], two on smoking, physical activity and weight [75,76], two on smoking, physical activity and nutrition [77-81], three on smoking, weight, nutrition and physical activity [82-84], one on smoking, alcohol, weight and physical activity [85], four studies on smoking, alcohol, nutrition and physical activity [38,86-89]. Four studies reported on all lifestyle behaviors included for this study [90-94]. Most studies $(n=36)$ were aimed at primary prevention, seven focused on secondary prevention following a diagnosis and seven aimed at both primary- and secondary prevention (see Table 1). Of the studies aimed at secondary prevention, three described patients diagnosed with heart or vascular disease [77$79,83,84]$, two reported on patients diagnosed with COPD $[54,76]$ and two described patients with type II diabetes $[82,88]$.

\subsubsection{Theoretical basis}

Twenty-three studies specified the theoretical basis of the intervention(s). Many interventions were based upon more than one theory. Prochaska's and DiClemente's transtheoretical model (TTM) or stages of change model was referred to as the theoretical idea behind interventions in twenty-one studies [37,39,40,42,46,47,49,51,54-56,61-63,65,69-71,73,80,81,83,88,89,93,94]. This model divides the process of behavioral change into five stages, from precontemplation to maintenance. In the articles, information on lifestyle behavior was adapted to a participant's readiness (stage of change) to adopt a new behavior. Eight studies [43,46,51,61,63,68,69,83] described an intervention based on Bandura's social learning theory or social cognitive theory (SCT). A central concept of this theory is self-efficacy. Self-efficacy is a person's sense of confidence in the ability to perform a particular behavior. Furthermore, one study [73] referred to Wagner's chronic disease care model. This model emphasizes the centrality of an informed activated patient within the care process. Another study [47] referred to the theory of planned behavior, which addresses attitudes and perceived behavioral control. Finally, the health belief model (HBM) was referred to [43]. This model uses perceived susceptibility, severity, benefits, barriers, cues to action and self-efficacy as constructs. 
Noordman, J., Weijden, T. van der, Dulmen, S. van. Communication-related behavior change techniques used in face-to-face lifestyle interventions in primary care: a systematic review of the literature. Patient Education and Counseling: 2012, 89(2), 227-244

Six studies described which constructs of the theory were chosen and translated into BCTs [39,43,46,68,69,73]. For example, Grandes and colleagues [43] described for each BCT whether it was

based on the HBM model, SCT model or both. Seventeen studies were less explicit about the connection between theory and BCT $[37,40,42,47,49,51,54-56,61-63,70,71,80,81,83,88,89,93,94]$.

\subsubsection{Intervention characteristics and outcome measures}

During the interventions, the face-to-face communication between patient and health care provider ranged from (seven studies with) one session [49,50,58,61,69-71,91] to (one study with) 15 sessions [83]. The number of face-to-face sessions does not include separate measurement sessions of biomedical or questionnaire data (only if part of the face-to-face BCT), telephone calls or written advice that were sometimes also part of the interventions. In three studies the frequency of the face-to- face communication sessions was not reported $[44,82,88]$.

The face-to-face communication sessions lasted from $30 \mathrm{~s}$ [37,55] to $60 \mathrm{~min}[54$ $72,89]$. Fourteen studies did not report the duration of the face-to-face sessions [40,44,46-48,65,70,75,76,82-84,88,90].

Most studies $(n=40)$ reported on both subjective (self- reported) and objective outcome measures. For example, Alterman and colleagues [52] described outcomes on cigarettes a day (subjective), carbon monoxide level and cotinine (objective measures). However, eight studies described self-reported out- comes only [44,48$51,59,62,68,79,88]$ and two studies exclusively objective outcomes [64,92]. As described above, the intensity of interventions and BCTs (number of face-to-face sessions and duration of sessions) differed to a great extent. Therefore, we could not determine the impact of intensity on outcomes.

\subsection{Face-to-face communication-related behavior change techniques}

In Table 2 the BCTs of the studies are provided, together with significant outcomes and the contribution of the health care providers.

In about half of the studies ( $\mathrm{n}=27$ ) more than one face-to-face communicationrelated BCT was used. These studies combined for example techniques such as advice and education [50,52,66,84,91] or goal setting, self-monitoring and motivational interviewing [42]. Twenty-three studies described single BCT, i.e. behavioral counseling or motivational interviewing or motivational message or patient-centered care (see Table 2). Hereby, a 'single' BCT refers to the label of the technique; i.e. a single technique could have more than one underlying working mechanism.

\subsubsection{Effective face-to-face communication-related behavior change techniques}

Twenty-eight of the 50 studies reported significant outcomes from the communication-related BCTs used in interventions. In principle, these BCTs were counted as effective. However, based on the principles of a 'Best Evidence Synthesis' twenty-six of the 28 studies provided some to moderate evidence for the BCT provided. This suggests that two studies [48, 91] provided only 'indicative 
Noordman, J., Weijden, T. van der, Dulmen, S. van. Communication-related behavior change techniques used in face-to-face lifestyle interventions in primary care: a systematic review of the literature. Patient Education and Counseling: 2012, 89(2), 227-244

findings'. Therefore, the BCTs in these studies, namely 'behavioral counseling and education' [48] and 'patient-centered care, advice and education' [91], were not counted as effective. The 26 effective studies represent a wide range of outcome measures and significant effects (Table 3 ). For smoking behavior the outcome measures presented are self-reported smoking rates (i.e. cigarettes a day) $[37,40,52,54,77,80,83,90]$ and biochemical measurement of carbon monoxide level $[37,40,52,80]$. With respect to alcohol use the studies present outcomes on selfreported alcohol use (i.e. drinks a day) [39,41,58,60,90] and blood alcohol concentration $[39,41,58,60]$.

Outcome measures described on nutrition are self-reported diet behavior (e.g. fat, fiber, fruit, vegetable, calorie intake) $[63,66,72,74,77,80,83,90]$ and measures as weight $[66,80,92]$, body mass index $[40,66,80,90]$ and waist circumference $[72,74]$, among others. On physical activity behavior the presented outcome measures are self-reported physical activity level $[43,44,46,49,70,72,74,77,80,83,90]$ and readiness for physical activity (self-efficacy) $[49,51,69]$. Studies also presented outcomes on blood pressure [46,66,80,90,92], lipid management [74,77] and quality of life $[43,70,83]$, among others (see Table 3).

The effective studies were also aimed at different patient populations within the context of primary care. For example, three of the effective studies [58,63,74] were aimed at a (moderately) low income population, of which one study [63] specifically indicated that 'differences were maintained when analyses were restricted to participants with low incomes' (Table 3). Eighty-one percent $(n=21)$ of the effective studies were of high quality.

Table 4 shows the 26 effective face-to-face communication- related BCTs. Sixteen of these studies outlined single BCTs [39-41,46,49,51,58,60,62,63,69$72,80,81,88,90,92]$ and ten studies described a combination of BCTs [37,43,44,52,54,55,66,68,74, 77-79,83]. 'Behavioral counseling' was most frequently used as an effective BCT (15 times out of 26), next to motivational interviewing (eight times out of 14), education (seven times out of 14) and advice (seven times out of 16). However, these results show that these techniques were also provided in less successful studies. These BCT were less successful because of the context of the study, as for example the design [56,75,84,86,94] or patient characteristics $[47,64,65]$. Although, all studies took place within the context of primary care and BCTs were always provided by a physician, nurse or both (in combination with other professionals, see Section 3.3). Besides, the less successful studies were more often of low quality (36\%) compared to the effective studies (19\%). Feedback, risk-assessment, goal-setting, cognitive behavior therapy and selfmonitoring were less often provided, but also showed significant effects on patients' outcomes. The effective face-to-face communication-related BCTs did not focus exclusively on one particular lifestyle behavior (e.g. smoking).

\section{[TABLE 4]}

Sixteen of the 26 effective studies described their theoretical foundation [37,39,40,43,44,46,49,51,54,55,62,63,68-71,80,81,83,88], of which five studies $[39,43,46,68,69]$ reported the chosen BCT constructs. 
Noordman, J., Weijden, T. van der, Dulmen, S. van. Communication-related behavior change techniques used in face-to-face lifestyle interventions in primary care: a systematic review of the literature. Patient Education and Counseling: 2012, 89(2), 227-244

\subsection{Contribution of health care providers}

Table 2 shows the contribution of the different health care providers, both as providers of effective and less successful BCTs.

Five of the 26 effective communication-related BCTs in primary care were provided by physicians $[44,49,66,69,88]$, eight by nurses [39,46,54,58,62,63,77-81,90] and five by both nurses and physi- cians [37,40,41,43,55,60,70,71]. In five studies the effective BCT was provided by physicians in combination with health educators [68], trained professionals [72], physical activity counselors [51], dieticians [92], or case managers [83]. In two studies the effective BCT was provided by nurses in combination with therapists [52], or nutritionists [74].

\section{DISCUSSION AND CONCLUSION}

\subsection{Discussion}

The present review shows that behavioral counseling, motivational interviewing, education and advice are most frequently evaluated as effective face-to-face communication-related BCTs. This overall conclusion could be drawn on the basis of finding relative many high quality studies in which communication- related BCTs prove to be effective. However, these techniques were also found in less successful studies due to differences in context, as design of the study and patient population, and to some extent the quality of the studies. Techniques such as feedback, riskassessment, goal-setting and cognitive behavior therapy seem to be less effective, although the number of studies on these techniques was rather small.

Our findings are partly in line with other studies in the field of behavior change which suggest that simple advice is more effective to behavior change than intensive advice [95] and as effective as motivational interviewing [18]. However, other studies $[24,26,96]$ suggest that advice and education are not effective, in contrast to more (intensive) patient-centered approaches. Our review did show that motivational interviewing (MI), which is considered a patient-centered approach [97], is also effective as BCT. Moreover, while MI is originally considered to be more a counseling style than a set of particular techniques [17], one can clearly describe MI as a set of techniques, containing the following elements: express empathy, develop discrepancy between present behavior and desired goals, avoid argumentation, roll with resistance and support self-efficacy [97,98]. In contrast, many of our included studies described the interventions and BCTs in general terms, like providing 'advice and education' or 'counseling sessions', which conceals underlying working mechanisms that may be crucial to the effectiveness of the BCT.

In line with others, we recommend future authors to describe the content of their interventions and BCTs more precisely [26,99-101]. According to Davidson et al. [101] among others [99], published articles should therefore include: (a) the content or elements of the intervention, (b) the characteristics of those delivering the intervention, (c) the characteristics of the recipients, (d) the setting, (e) the mode of delivery (e.g. face-to-face), (f) the intensity (e.g. contact time), (g) the duration (e.g. number of sessions over a given period), and (h) adherence to delivery protocols. Michie et al. [20] plead for the use of theory-based interventions to understand the causal determinants of behavior change among other things. Our review demonstrates that no more than about half of the studies used a theory as basis for the intervention. However, sixteen out of the 26 effective studies described their 
Noordman, J., Weijden, T. van der, Dulmen, S. van. Communication-related behavior change techniques used in face-to-face lifestyle interventions in primary care: a systematic review of the literature. Patient Education and Counseling: 2012, 89(2), 227-244

theoretical foundation. Yet, these interventions were mostly theory-inspired instead of theory-based, i.e. the authors seldom linked (aspects of) the theory to the BCT used. Hence, next to the guidelines presented by Davidson et al. [101] a published article should also describe the theoretical basis of the intervention and BCTs used to get insight into the underlying working mechanisms [99,100]. Furthermore, we imagine that other elements are also of importance to be routinely reported e.g. amount of training and supervision of professionals, follow-up contacts and implementation fidelity.

We also found that physicians, nurses or a combination of these (sometimes in combination with other professionals) can provide effective face-to-face communication-related BCTs in primary care. Within primary care one profession (physician) does not seem to be better than the other (nurse) in providing face-to-face communica- tion-related BCTs. However, we have to be cautious with this conclusion as we found only a few studies that included both physicians and nurses as health care providers. Since providing these BCTs can be time consuming for a single person or profession, an opportunity lies in dividing the workload or delegate certain tasks to another profession. Within this 'collaborative model of care' physicians provide care (e.g. provide diagnosis, screening, initiate treatment) and nurses deliver the counseling to patients (e.g. follow- up, support self-management) [55,102]. Therefore, proper task arrangements between physicians and nurses should be made. A recent study on cardiovascular prevention in the Netherlands did show that lifestyle intervention advice is in fact more frequently given by PNs than by GPs [28]. However, this study was based on self-reported information about lifestyle advice given, so we do not know if and how lifestyle is actually discussed in the consulting room. Future studies should therefore investigate how behavior change in lifestyle interventions is being discussed in the consulting room, both in quantity and content.

While population and public health approaches are widely used to change risk related to unhealthy lifestyle, governments more and more stress people's individual responsibility [103,104]. They claim that people can make their own decisions concerning lifestyle, although support and reliable information should be available to come to a conscious decision. This is fairly in line with the principle of motivational interviewing, which focuses on the motivation of patients to change behavior instead of health care providers telling them what to do. Depending on the patients' motivational 'stage of change' a health care provider can offer specific information and advice to help a patient overcome resistance toward behavior change [105]. The finding that goal setting does not seem to be an effective technique deserves further attention in this respect.

Lastly, this review demonstrates a lack of knowledge about face-to-face communication-related BCTs; there is a lack of theoretical foundation of interventions and BCTs, diversity in intensity of interventions and the content of techniques. Besides, we do not know whether every BCT is actually applicable within primary care and for every patient. Although Abraham and Michie [99] provide a crucial first step by presenting a taxonomy of BCTs, as far as we know this taxonomy has not yet been used in interventions within behavior change research and techniques were only identified for HIV/AIDS, physical activity and healthy eating.

\subsubsection{Strengths and limitations}


Noordman, J., Weijden, T. van der, Dulmen, S. van. Communication-related behavior change techniques used in face-to-face lifestyle interventions in primary care: a systematic review of the literature. Patient Education and Counseling: 2012, 89(2), 227-244

This is the first review, to our knowledge, that examines physicians' and nurses’ (working within primary care) provision of face-to-face communication-related BCTs to patients. Another strength of this review is that we only included studies with rigorous design (RCTs) that reported effects on actual patient behavior. Besides, our results were not dominated by large numbers of studies on a particular lifestyle behavior (e.g. smoking behavior); all lifestyle behaviors were addressed in relation to the (effective) BCTs. In addition, we specifically choose 'face-to-face' as form of delivery to avoid confounding with other modes of delivery.

Some limitations should also be noted. First, while we made an effort to create a thorough search strategy, it is possible that we failed to include all studies in this area due to publication bias and excluding non-English language studies. Second, in our quality assessment we relied on the methodology information that was reported in the articles. When information was missing we scored the item as 'unclear', without verifying this by contacting the authors of the sometimes relatively 'old' articles. When an article referred to another (not included) article for methodological information, we did, however, base our quality assessment on all available methodological information described in both articles. In addition, it is possible that the large amount of 'high quality' studies in this review is due to our small adjustment of the number of quality criteria. Third, as mentioned before, the content of the interventions and BCTs were not always sufficiently described. Therefore, we could not report the underlying working mechaisms that may be critical to the effectiveness of the face-to-face communication-related BCTs. Also, this general description of the BCTs may suggest that when a technique is labeled as for example 'behavioral counseling' the content is always the same, while the technique could mean different things in different studies. Furthermore, we do not know whether the health care providers in the included studies delivered the face-to-face communication-related BCTs in a suitable and intended way, since this was not described. Besides, it was difficult to compare studies because of the different outcome measures they presented. However, it is still possible that some behaviors are more sensitive to BCTs than others. Lastly, although we only included studies with 'face-to-face' as form of delivery, it is possible that other elements of the intervention, for example providing medication or the intensity and duration of the intervention, also contributed to the outcomes of the BCT.

\subsection{Conclusion}

This review demonstrates that behavioral counseling, motivational interviewing, education and advice are all evaluated as effective communication-related BCTs. However, these BCTs were also found in less successful studies due to differences in context, as design of the study or patient population, and to some extent quality of the studies. Furthermore, based on existing literature, one primary care profession (physician) does not seem better equipped than the other (nurse) to provide face-toface communication-related BCTs.

\subsection{Practice implications}

There is some evidence that behavioral counseling, motiva- tional interviewing, education and advice can be used as effective communication-related BCTs by physicians and nurses. However, further research is needed to examine the underlying working mechanisms of communication-related BCTs, and whether they 
Noordman, J., Weijden, T. van der, Dulmen, S. van. Communication-related behavior change techniques used in face-to-face lifestyle interventions in primary care: a systematic review of the literature. Patient Education and Counseling: 2012, 89(2), 227-244

meet the requirements of patients and primary care providers. Observing real-life consultations between primary care professionals and patients can provide a first insight into the content and mechanisms of the communication-related BCT, used to intervene on patients' lifestyle behavior.

\section{Conflict of interest}

The authors declare that they have no competing interests.

\section{Acknowledgements}

We thank Harm-Wouter Snippe and William Verheul for creating a very useful digital tool which helped us to easily select our references based on title and abstract. We also thank Linda Schoonmade for her help in creating a proper search strategy and Patriek Mistiaen for his advice about methodological aspects of our review. This study was funded by the Dutch Ministry of Health, Welfare and Sport.

Appendix A. Search Strategy PubMed

Search Strategy PubMed dd. 11-10-2010

\begin{tabular}{|c|c|c|}
\hline Search & Search terms & Results \\
\hline$\# 1$ & $\begin{array}{l}\text { "Life Style"[ Majr] OR "lifestyle"[tiab] OR "healthy } \\
\text { behavior" [tiab] OR "healthy behaviour"[tiab] OR } \\
\text { "health behavior"[tiab] OR "health behaviour"[tiab] } \\
\text { OR “unhealthy behavior" [tiab] OR "unhealthy } \\
\text { behaviour"[tiab]OR "behavior change"[tiab] OR } \\
\text { "behavior change"[tiab]OR smoking[tiab] OR alcohol } \\
\text { [tiab] OR nutrition[tiab] OR "eating habits"[tiab] OR } \\
\text { "physical activity" OR "Exercise"[Majr] OR exercise } \\
\text { [tiab] OR "Alcohol Drinking"[Majr] OR } \\
\text { "Smoking"[Majr] OR "Eating"[Majr] }\end{array}$ & 545,534 \\
\hline \#2 & 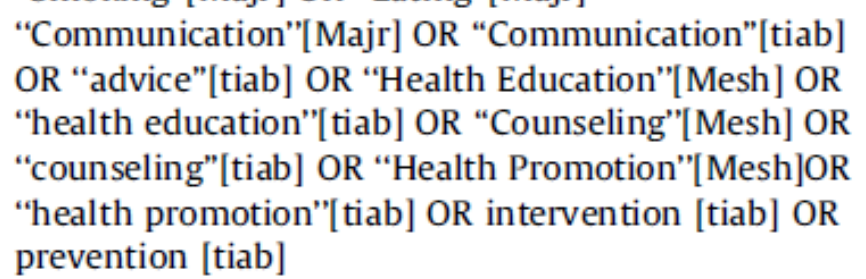 & 887,763 \\
\hline \#3 & $\begin{array}{l}\text { "Primary Health Care"[Mesh] OR "primary care" } \\
\text { [tiab] OR "Primary Nursing Care"[ Mesh] OR } \\
\text { "Physicians, Family"[Mesh] OR "family physician" } \\
\text { [tiab] OR "family physicians" [tiab] OR "general } \\
\text { practitioner" [tiab] OR "general practitioners" [tiab] } \\
\text { OR "primary physician"[tiab] OR "primary } \\
\text { physicians" [tiab] OR "family doctor"[tiab] OR } \\
\text { "family doctors" [tiab] OR "practice nurse" [tiab] OR } \\
\text { "practice nurses" [tiab] OR "Nurse } \\
\text { Practitioners"[ Mesh] OR "Nurse Practitioner"[tiab] } \\
\text { OR "nurse practitioners"[tiab] }\end{array}$ & 144,152 \\
\hline$\# 4$ & $\begin{array}{l}\text { “HIV"[Mesh] OR “Neoplasms"[Mesh] OR } \\
\text { "cancer”[tiab] OR “Mental Health"[Mesh] OR } \\
\text { "Review" [Publication Type] }\end{array}$ & $3,653,987$ \\
\hline \#5 & \#1 AND \#2 AND \#3 NOT \#4 & 3856 \\
\hline
\end{tabular}


Noordman, J., Weijden, T. van der, Dulmen, S. van. Communication-related behavior change techniques used in face-to-face lifestyle interventions in primary care: a systematic review of the literature. Patient Education and Counseling: 2012, 89(2), 227-244

Tiab, title and abstract; Majr, major mesh term; Mesh, mesh term.

Search \#5 was selected and 3856 references were included in the original literature list.

\section{Appendix B. Operationalization of criteria for assessment of methodological quality [32]}

Validity criteria (yes, no, unclear):

1. Was the method of randomization adequate?1

2. Was the treatment allocation concealed?

3. Were the groups similar at baseline regarding the most important prognostic indicators?

4. Was the patient blinded to the intervention?

5. Was the care provider blinded to the intervention?

6. Was the outcome assessor blinded to the intervention?

7. Were co-interventions avoided or similar?

8. Was the compliance acceptable in all groups?

9. Was the drop out rate described and acceptable?

10. Was the timing of the outcome assessment in all groups similar?

11. Did the analysis include an intention-to-treat analysis?

\section{Methodological quality:}

High quality: the study adequately fulfilled $50 \%$ or more of the validity criteria (6 or more out of 11 criteria).

Low quality: the study fulfilled less than $50 \%$ of the validity criteria ( $<6$ out of 11 criteria).

\section{Operationalization of the criteria list}

1. Was the method of randomization adequate, e.g. at patient level? Examples of adequate methods are computer generated random number table and use of sealed opaque envelopes. Score yes if the above is the case. Score no if a transparent system is used and score do not know when the method of randomization is not described in the article.

2. Was the assignment generated by an independent person not responsible for determining the eligibility of the patients? This person has no information about the persons included in the study and has no influence on the assignment sequence or on the decision about the eligibility of the patients. Score yes when the assignment has been taken place by an independent person. Score no if the above is not the case and score do not know if no information is given about who generated the assignment.

3. Are important prognostic indicators assessed at baseline? Are there no substantial differences between the intervention group and the control group (for example regarding age, sex, type of cancer, duration of the disease, stadium of the disease, cognitive status and type of treatment). Score yes if the above is the case and score no if there are differences regarding the prognostic indicators at baseline that could undermine post intervention differences. Score also no if no testing has been done to check if there were actual differences (a table with prognostic indicators without explanation is 
Noordman, J., Weijden, T. van der, Dulmen, S. van. Communication-related behavior change techniques used in face-to-face lifestyle interventions in primary care: a systematic review of the literature. Patient Education and Counseling: 2012, 89(2), 227-244

not enough). Score do not know when no information had been given about prognostic indicators.

4. Was the patient blinded to the intervention? The reviewer determines if enough information is given in order to score a

5. 'yes'. Score do not know if no information is given.

6. Was the care provider blinded to the intervention? The reviewer determines if enough information is given in order to score a 'yes'. Score do not know if no information is given.

7. Was the outcome assessor blinded to the intervention? The reviewer determines if enough information is given in order to score a 'yes'. Score do not know if no information is given.

8. Were co-interventions avoided in the design or were they similar between the intervention groups and control group? Score yes if the above is the case. Score no if there were co- interventions, not similar for the different groups. Score also no when no information has been given about co interventions (so, not tested is also no). Note. This criterion cannot be decisive in determining low quality of an article.

9. Was the compliance rate among patients evaluated (e.g. did they view the received video or read the written material)?

10. Score yes if the percentage of patients that used the

11. intervention is above $70 \%$ in all groups. Score no if this percentage is below $70 \%$ and score do not know if no information about compliance has been given.

12. Is the number of patients described (and reasons given) that were included in the study but did not complete the intervention or were excluded from analysis? Is this percent- age of withdrawals or drop-outs acceptable? Score yes if there is information from 80 to $100 \%$ of the randomized patients about the outcome assessment of recall. Score no if there is information from less than $80 \%$ of the randomized patients and score do not know if no information about withdrawals or drop-outs has been given.

13. Was the timing of the outcome assessment in all groups similar? Score yes if the above is the case (score also yes if a range is described, provided that this range does not have a large spread, for example more than three months). Score no if the timing of outcome assessment was not similar for all groups and score do not know if no information about the timing was given.

14. Was all available data included for analysis (intention to treat)?

15. This means that all randomized patients were analyzed in the group they were assigned to regardless of noncompliance and co-interventions. Score yes if the above is the case, score no when the analysis did not include an intention to treat analysis. Score do not know if no information about intention to treat is given.

\section{Appendix C. Principles of the best evidence synthesis [36]}

Evidence: Provided by consistent, statistically significant findings in outcome measures in at least two high quality RCTs.

Moderate evidence: Provided by consistent, statistically significant findings in outcome measures in at least one high quality RCT and at least one moderate or low quality RCT. 
Noordman, J., Weijden, T. van der, Dulmen, S. van. Communication-related behavior change techniques used in face-to-face lifestyle interventions in primary care: a systematic review of the literature. Patient Education and Counseling: 2012, 89(2), 227-244

Limited evidence: Provided by statistically significant findings in outcome measures in at least one high quality RCT.

Indicative findings: Provided by statistically significant findings in outcome measures in at least one moderate or low quality RCT (in the absence of high quality RCTs) No/insufficient evidence: If the number of studies that have significant findings is less than $50 \%$ of the total number of studies found within the same category of methodological quality and study design.

Or

In case the results of eligible studies do not meet the criteria for one of the above stated levels of evidence.

Or

In case of conflicting (statistically significantly positive and statistically significantly negative) results among RCTs.

Or

In case of no eligible studies.

\section{REFERENCES}

[1] Blank L, Grimsley M, Goyder E, Ellis E, Peters J. Community-based lifestyle interventions: changing behaviour and improving health. J Public Health 2007;29:236-45.

[2] King D, Mainous III AG, Carnemolla M, Everett CJ. Adherence to healthy lifestyle habits in US adults, 1988-2006. Amer J Med 2009;122:528-34.

[3] Li C, Ford ES, Mokdad AH, Jiles R, Giles WH. Clustering of multiple healthy lifestyle habits and health-related quality of life among US adults with diabetes. Diabetes Care 2007;30:1770-6.

[4] Van Wayenburg CAM, Lemiengre MBT, Van Reenen-Schimmel AH, Bor JHJ, Bakx JC, Van Staveren WA, et al. Encounters for common illnesses in general practice increased in obese patients. Fam Pract 2008;25:93-8.

[5] Casswell S, Thamarangsi T. Reducing harm from alcohol: call to action. Lancet 2009;373:2247-57.

[6] Allin S, Mossialos E, McKee M, Holland W. Making decisions on public health. A review of eight countries. Eur Observ Health Care Syst Policies 2004.

[7] Gezondheidsraad. Voor dik en dun. Preventie van overgewicht en obesitas en het risico van eetstoornissen. Prevention of overweight and obesity and the risk of eating discorders Den Haag: Gezondheidsraad; 2010.

[8] VWS. Preventienota Kiezen voor gezond leven. Brief van de minister aan de

Tweede Kamer. Prevention note Choosing healthy life Den Haag: VWS; 2006 [Ministerie van Volksgezondheid, Welzijn en Sport].

[9] VWS. Gezond zijn, gezond blijven: Een visie op gezondheid en preventie Being healthy, staying healthy In: A vision of health and prevention. Den Haag: VWS;

2007 [Ministerie van Volksgezondheid, Welzijn en Sport].

[10] Nielen MMJ, Assendelft WJJ, Drenthen AJM, Van Den Hombergh P, Van Dis I,

Schellevis FG. Primary prevention of cardio-metabolic diseases in general practice: a Dutch survey of attitudes and working methods of general practi- tioners. Eur J Gen Pract 2010;16:139-42.

[11] Hibble A. Practice nurse workload before and after the introduction of the 1990 contract for general practitioners. Br J Gen Pract 1995;45:35-7.

[12] Laurant M. Changes in skill mix: the impact of adding nurses tot the primary care team. Nijmegen: Radboud University; 2007.

[13] Richards A, Carley J, Jenkins-Clarke S, Richards DA. Skill mix between nurses and doctors working in primary-care delegation or allocation: a review of the literature. Int $\mathrm{J}$ Nurs Stud 2000;37:185-7.

[14] Landelijke Huisartsen Vereniging (LHV). Handreiking competentieprofiel en 
Noordman, J., Weijden, T. van der, Dulmen, S. van. Communication-related behavior change techniques used in face-to-face lifestyle interventions in primary care: a systematic review of the literature. Patient Education and Counseling: 2012, 89(2), 227-244

eindtermen praktijkondersteuner. http://lhv.artsennet.nl/LHVproduct/Han- dreikingCompetentieprofiel-en-eindtermen-Praktijkondersteuner-1.htm;

30 January 2012.

[15] Heijmans M, Spreeuwenberg P, Rijken M. Ontwikkelingen in de zorg voor chronische zieken: rapportage 2010. Utrecht: NIVEL; 2010 [Developments in care for chronic diseases: report 2010].

[16] Britt E, Hudson S, Blampied N. Motivational interviewing in health settings: a review. Patient Educ Couns 2004;53:147-55.

[17] Miller WR. Motivational interviewing: research, practice and puzzles. Addict Behav 1996;21:835-42.

[18] Davis MF, Shapiro D, Windsor R, Whalen P, Rhode R, Miller HS, et al. Motiva- tional interviewing versus prescriptive advice for smokers who are not ready to quit. Patient Educ Couns 2011;83:129-33.

[19] Eriksson MK, Hagberg L, Lindholm L, Malmgren-Olsson EB, Osterlind J, Eliasson M. Quality of life and cost-effectiveness of a 3-year trial of lifestyle interven- tion in primary health care. Arch Intern Med 2010;170:1470-9.

[20] Michie S, Johnston M, Francis J, Hardeman W, Eccles M. From theory to intervention: mapping theoretically derived behavioural determinants to behaviour change techniques. Appl Psychol 2008;57:660-70.

[21] Lancaster T, Stead L, Silagy C, Sowden A. Effectiveness of interventions to help people stop smoking: findings from the Cochrane Library. Brit Med J

2000;321:355-8.

[22] Papadakis S, McDonald P, Mullen KA, Reid R, Skulsky K, Pipe A. Strategies to increase the delivery of smoking cessation treatments in primary care set- tings: a systematic review and meta-analysis. Prev Med 2010;51:199-203.

[23] Eakin EG, Glasgow RE, Riley KM. Review of primary care-based physical activity intervention studies. J Fam Pract 2000;49:158-68.

[24] Lawlor DA, Hanratty B. The effect of physical activity advice given in routine primary care consultations: a systematic review. J Public Health Med

2001;23:219-26.

[25] Knight K, McGowan L, Dickens C, Bundy C. A systematic review of motivational interviewing in physical health care setting. Br J Health Psychol 2006;11:319_ 22.

[26] Van Achterberg T, Huisman-de Waal G, Ketelaar N, Oostendorp RA, Jacobs J, Wollersheim $\mathrm{H}$. How to promote healthy behaviours in patients. An overview of evidence for behaviour change techniques. Health Promot Int 2011;26:148-

52.

[27] Lenz ER, Mundinger MO, Hopkins SC, Lin SX, Smolowitz JL. Diabetes care processes and outcomes in patients treated by nurse practitioners or physi- cians. Diabetes Educ 2002;28:590-8.

[28] Voogdt-Pruis HR, Van Ree JW, Gorgels APM, Beusmans GHMI. Adherence to a guideline on cardiovascular prevention: a comparison between general prac- titioners and practice nurses. Int J Nurs Stud 2011;48:798-807.

[29] van Zuilen AD, Wetzels JFM, Bots ML, Blankestijn PJ. MASTERPLAN: study of the role of nurse practitioners in a multifactorial intervention to reduce cardiovas- cular risk in chronic kidney disease patients. J Nephrol 2008;21:261-7.

[30] Ockene JK, Adams A, Hurley TG, Wheeler EV, Hebert JR. Brief physician- and nurse practitioner-delivered counseling for high-risk drinkers: does it work. Arch Intern Med 1999;159:2198-205.

[31] Reiff-Hekking S, Ockene JK, Hurley TG, Reed GW. Brief physician and nurse practitioner-delivered counseling for high-risk drinking: results at 12-month follow-up. J Gen Intern Med 2005;20:3-7.

[32] Van Tulder M, Furlan A, Bombardier C, Bouter L. Updated method guidelines for systematic reviews in the Cochrane Collaboration Back Review Group. Spine 2003;28:1290-9.

[33] Higgens J, Green S. Cochrane handbook for systematic reviews of interventions 
Noordman, J., Weijden, T. van der, Dulmen, S. van. Communication-related behavior change techniques used in face-to-face lifestyle interventions in primary care: a systematic review of the literature. Patient Education and Counseling: 2012, 89(2), 227-244

Version 5.0.2 (updates September 2009). The Cochrane Collaboration; 2009. [34] Morren M Van Dulmen S, Ouwerkerk J, Bensing JM. Compliance with mo- mentary pain measurement using electronic diaries: a systematic review. Eur J

Pain 2009;13:354-5.

[35] Van Tulder MW, Cherkin DC, Berman B, Lao L, Koes BW. Accupuncture for low back pain. The Cochrane Library; 2002.

[36] Steultjens E, Dekker J, Bouter LM, Nes J, van de, Cardol M, et al. Occupational therapy for multiple sclerosis. The Cochrane Library; 2002 [Protocol for a Cochrane Review].

[37] Hollis JF, Lichtenstein E, Mount K, Vogt TM, Stevens VJ. Nurse-assisted smoking counseling in medical settings: minimizing demands on physicians. Prev Med 1991;20:497-507.

[38] Koelewijn-van Loon MS, Van Der Weijden T, Ronda G, van Steenkiste B, Winkens B, Elwyn G, et al. Improving lifestyle and risk perception through patient involvement in nurseled cardiovascular risk management: a cluster- randomized controlled trial in primary care. Prev Med 2010;50:35-44.

[39] Noknoy S, Rangsin R, Saengcharnchai P, Tantibhaedhyangkul U, McCambridge J. RCT of effectiveness of motivational enhancement therapy delivered by nurses for hazardous drinkers in primary care units in Thailand. Alcohol

2010;45:263-70.

[40] Ramos M, Ripoll J, Estrades T, Socias I, Fe A, Duro R, et al. Effectiveness of intensive group and individual interventions for smoking cessation in primary health care settings: a randomized trial. BMC Public Health 2010;10:89.

[41] Rubio G, Jimenez-Arriero MA, Martinez I, Ponce G, Palomo T. Efficacy of physiciandelivered brief counseling intervention for binge drinkers. Am J Med 2010;123:72-8.

[42] Armit CM, Brown WJ, Marshall AL, Ritchie CB, Trost SG, Green A, et al.

Randomized trial of three strategies to promote physical activity in general practice. Prev Med 2009;48:156-63.

[43] Grandes G, Sanchez A, Sanchez-Pinilla RO, Torcal J, Montoya I, Lizarraga K, et al.

Effectiveness of physical activity advice and prescription by physicians in routine primary care a cluster randomized trial. Arch Intern Med

2009;169:694-701.

[44] Kerse NM, Flicker L, Jolley D, Arroll B, Young D. Improving the health beha- viours of elderly people: randomised controlled trial of a general practice education programme. Brit Med J 1999;319:683-7.

[45] Lawton BA, Rose SB, Elley CR, Dowell AC, Fenton A, Moyes SA. Exercise on prescription for women aged 40-74 recruited through primary care: two year randomised controlled trial. Brit Med J 2008;337:a2509.

[46] Lee LL, Arthur A, Avis M. Evaluating a community-based walking intervention for hypertensive older people in Taiwan: a randomized controlled trial. Prev Med 2007;44:1606.

[47] Little P, Dorward M, Gralton S, Hammerton L, Pillinger J, White P, et al. A randomised controlled trial of three pragmatic approaches to initiate in- creased physical activity in sedentary patients with risk factors for cardiovas- cular disease. Br J Gen Pract 2004;54:189-95.

[48] Reed J, Malvern L, Muthukrishnan S, Hardy R, King L. An ecological approach with primary-care counseling to promote physical activity. J Phys Act Health

2008;5:169-73.

[49] Spink KS, Reeder B, Chad K, Wilson K, Nickel D. Examining physician counsel- ling to promote the adoption of physical activity. Can J Public Health 2008;99:26-30.

[50] Swinburn BA, Walter LG, Arroll B, Tilyard MW, Russell DG. The green pre- scription study: a randomized controlled trial of written exercise advice provided by general practitioners. Am J Public Health 1998;88:288-91.

[51] Van Sluijs EMF, Van Poppel MNM, Twisk JWR, Brug J, Van Mechelen W. The positive effect on determinants of physical activity of a tailored, general practice- based physical activity intervention. Health Educ Res 2005;20:345-6.

[52] Alterman AI, Gariti P, Mulvaney F. Short-and long-term smoking cessation for three levels of intensity of behavioral treatment. Psychol Addict Behav 
Noordman, J., Weijden, T. van der, Dulmen, S. van. Communication-related behavior change techniques used in face-to-face lifestyle interventions in primary care: a systematic review of the literature. Patient Education and Counseling: 2012, 89(2), 227-244

2001;15:261-4.

[53] Aveyard P, Brown K, Saunders C, Alexander A, Johnstone E, Munafo MR, et al.

Weekly versus basic smoking cessation support in primary care: a randomised controlled trial. Thorax 2007;62:898-903.

[54] Efraimsson EO, Hillervik C, Ehrenberg A. Effects of COPD self-care management education at a nurse-led primary health care clinic. Scand J Caring Sci

2008;22:178-85.

[55] Hollis JF, Lichtenstein E, Vogt TM, Stevens VJ, Biglan A. Nurse-assisted counsel- ing for smokers in primary care. Ann Intern Med 1993;118:521-5.

[56] Lancaster T, Dobbie W, Katrina V, Yudkin P, Murphy M, Fowler G. Randomized trial of nurse-assisted strategies for smoking cessation in primary care. $\mathrm{Br} \mathrm{J}$ Gen Pract 1999;49:191-4.

[57] Aalto M, Saksanen R, Laine P, Forsstrom R, Raikaa M, Kiviluoto M, et al. Brief intervention for female heavy drinkers in routine general practice: a 3-year randomized, controlled study. Alcohol Clin Exp Res 2000;24:1680-6.

[58] Beckham N. Motivational interviewing with hazardous drinkers. J Am Acad Nurse Pract 2007;19:103-10.

[59] Beich A, Gannik D, Saelan H, Thorsen T. Screening and brief intervention targeting risky drinkers in Danish general practice-a pragmatic controlled trial. Alcohol 2007;42:593-603.

[60] Schaus JF, Sole ML, McCoy TP, Mullett N, O'Brien MC. Alcohol screening and brief intervention in a college student health center: a randomized controlled trial. J Stud Alcohol Drugs Suppl 2009;16:131-41.

[61] Beresford SA, Curry SJ, Kristal AR, Lazovich D, Feng Z, Wagner EH. A dietary intervention in primary care practice: the eating patterns study. Am J Public Health 1997;87:610-6.

[62] Steptoe A, Doherty S, Kerry S, Rink E, Hilton S. Sociodemographic and psy- chological predictors of changes in dietary fat consumption in adults with high blood cholesterol following counseling in primary care. Health Psychol

2000;19:411-9.

[63] Steptoe A, Perkins-Porras L, McKay C, Rink E, Hilton S, Cappuccio FP. Behavioural counselling to increase consumption of fruit and vegetables in low income adults: randomised trial. Brit Med J 2003;326:855-8.

[64] ter Bogt NCW, Bemelmans WJE, Beltman FW, Broer J, Smit AJ, van der Meer K. Preventing weight gain. One-year results of a randomized lifestyle interven- tion. Am J Prev Med 2009;37:270-7.

[65] Reid CM, Maher T, Jennings GL. Substituting lifestyle management for pharmacological control of blood pressure: a pilot study in Australian general practice. Blood Press 2000;9:267-74.

[66] Sacerdote C, Fiorini L, Rosato R, Audenino M, Valpreda M, Vineis P. Random- ized controlled trial: effect of nutritional counselling in general practice. Int J Epidemiol 2006;35:409-15.

[67] Willaing I, Ladelund S, Jorgensen T, Simonsen T, Nielsen LM. Nutritional counselling in primary health care: a randomized comparison of an inter- vention by general practitioner or dietician. Eur J Cardiovasc Prev Rehabil

2004;11:513-20.

[68] Anderson RT, King A, Stewart AL, Camacho F, Rejeski WJ. Physical activity counseling in primary care and patient well-being: do patients benefit. Ann Behav Med 2005;30:14654.

[69] Bolognesi M, Nigg CR, Massarini M, Lippke S. Reducing obesity indicators through brief physical activity counseling (PACE) in Italian primary care settings. Ann Behav Med 2006;31:179-85.

[70] Elley CR, Kerse N, Arroll B, Robinson E. Effectiveness of counselling patients on physical activity in general practice: cluster randomised controlled trial. Brit Med J 2003;326:793-6.

[71] Kerse N, Elley CR, Robinson E, Arroll B. Is physical activity counseling effective for older people? A cluster randomized, controlled trial in primary care. J Am Geriatr Soc 2005;53:1951-6. 
Noordman, J., Weijden, T. van der, Dulmen, S. van. Communication-related behavior change techniques used in face-to-face lifestyle interventions in primary care: a systematic review of the literature. Patient Education and Counseling: 2012, 89(2), 227-244

[72] Bo S, Ciccone G, Baldi C, Benini L, Dusio F, Forastiere G, et al. Effectiveness of a lifestyle intervention on metabolic syndrome. A randomized controlled trial. J Gen Intern Med 2007;22:1695-703.

[73] Logue E, Sutton K, Jarjoura D, Smucker W, Baughman K, Capers C. Trans-

theoretical model-chronic disease care for obesity in primary care: a ran- domized trial. Obes Res 2005;13:917-27.

[74] Whittemore R, Melkus G, Wagner J, Dziura J, Northrup V, Grey M. Translating the diabetes prevention program to primary care: a pilot study. Nurs Res

2009;58:2-12.

[75] Ketola E, Ma" kela" M, Klockars M. Individualised multifactorial lifestyle inter- vention trial for high-risk cardiovascular patients in primary care. Br J Gen Pract 2001;51:291-4.

[76] Van Den Bemt L, Schermer TRJ, Smeele IJM, Boonman-de Winter LJM, Van Boxem T, Denis J, et al. An expert-supported monitoring system for patients with chronic obstructive pulmonary disease in general practice: results of a cluster randomised controlled trial. Med J Aust 2009;191:249-54.

[77] Campbell NC, Ritchie LD, Thain J, Deans HG, Rawles JM, Squair JL. Secondary prevention in coronary heart disease: a randomised trial of nurse led clinics in primary care. Heart 1998;80:447-52.

[78] Murchie P, Campbell NC, Ritchie LD, Simpson JA, Thain J. Secondary preven- tion clinics for coronary heart disease: four year follow up of a randomised controlled trial in primary care. Brit Med J 2003;326:84-7.

[79] Murchie P, Campbell NC, Ritchie LD, Deans HG, Thain J. Effects of secondary prevention clinics on health status in patients with coronary heart disease: 4 year follow-up of a randomized trial in primary care. Fam Pract 2004;21:

567-74.

[80] Steptoe A, Doherty S, Rink E, Kerry S, Kendrick T, Hilton S. Behavioural counselling in general practice for the promotion of healthy behaviour among adults at increased risk of coronary heart disease: randomised trial. Brit Med J

1999;319:943-7.

[81] Steptoe A, Kerry S, Rink E, Hilton S. The impact of behavioral counseling on stage of change in fat intake, physical activity, and cigarette smoking in adults at increased risk of coronary heart disease. Am J Public Health 2001;91:

265-9.

[82] Kinmonth AL, Woodcock A, Griffin S, Spiegal N, Campbell MJ. Randomised controlled trial of patient centred care of diabetes in general practice: impact on current wellbeing and future disease risk. Brit Med J 1998;317:1202-8.

[83] Lear SA, Spinelli JJ, Linden W, Brozic A, Kiess M, Frohlich JJ, et al. The extensive lifestyle management intervention (ELMI) after cardiac rehabilitation: a 4- year randomized controlled trial. Am Heart J 2006;152:333-9.

[84] Munoz MA, Vila J, Cabanero M, Rebato C, Subirana I, Sala J, et al. Efficacy of an intensive prevention program in coronary patients in primary care, a ran- domised clinical trial. Int J Cardiol 2007;118:312-20.

[85] McManus RJ, Mant J, Roalfe A, Oakes RA, Bryan S, Pattison HM, et al. Targets and self monitoring in hypertension: randomised controlled trial and cost effectiveness analysis. Brit Med J 2005;331:93.

[86] Burton LC, Paglia MJ, German PS, Shapiro S, Damiano AM. The effect among older persons of a general preventive visit on three health behaviors: smok- ing, excessive alcohol drinking, and sedentary lifestyle. Prev Med

1995;24:492-7.

[87] Koelewijn-van Loon MS, Van Der Weijden T, van Steenkiste B, Ronda G, Winkens B, Severens $\mathrm{JL}$, et al. Involving patients in cardiovascular risk management with nurse-led clinics: a cluster randomized controlled trial. CMAJ 2009;181:E267-74.

[88] Rubak S, Sandbaek A, Lauritzen T, Borch-Johnsen K, Christensen B. General practitioners trained in motivational interviewing can positively affect the attitude to behaviour change in people with type 2 diabetes. One year follow- up of an RCT, ADDITION Denmark. Scand J Prim Health Care 2009;27:172-9. 
Noordman, J., Weijden, T. van der, Dulmen, S. van. Communication-related behavior change techniques used in face-to-face lifestyle interventions in primary care: a systematic review of the literature. Patient Education and Counseling: 2012, 89(2), 227-244

[89] Tonstad S, Alm CS, Sandvik E. Effect of nurse counselling on metabolic risk factors in patients with mild hypertension: a randomised controlled trial. Eur J Cardiovasc Nurs 2007;6:160-4.

[90] Kastarinen MJ, Puska PM, Korhonen MH, Mustonen JN, Salomaa VV, Sundvall JE, et al. Non-pharmacological treatment of hypertension in primary health care: a 2-year open randomized controlled trial of lifestyle intervention against hypertension in eastern Finland. J Hypertens 2002;20:2505-2.

[91] Lauritzen T, Jensen MS, Thomsen JL, Christensen B, Engberg M. Health tests and health consultations reduced cardiovascular risk without psychological strain, increased healthcare utilization or increased costs. An overview of the results from a 5-year randomized trial in primary care. The Ebeltoft Health Promotion Project (EHPP). Scand J Public Health 2008;36:650-1.

[92] Pritchard DA, Hyndman J, Taba F. Nutritional counselling in general practice: a cost effective analysis. J Epidemiol Commun Health 1999;53:311-6.

[93] Woollard J, Burke V, Beilin LJ, Verheijden M, Bulsara MK. Effects of a general practicebased intervention on diet, body mass index and blood lipids in patients at cardiovascular risk. Eur J Cardiovasc Prev Rehabil 2003;10:31-40.

[94] Woollard J, Burke V, Beilin LJ. Effects of general practice-based nurse-coun- selling on ambulatory blood pressure and antihypertensive drug prescription in patients at increased risk of cardiovascular disease. J Hum Hypertens

2003;17:689-95.

[95] Stead LF, Bergson G, Lancaster T. Physician advice for smoking cessation. The Cochrane Collaboration 2008;4:1-6 [Review].

[96] Baker MK, Simpson K, Lloyd B, Bauman AE, Singh MA. Behavioral strategies in diabetes prevention programs: a systematic review of randomized controlled trials. Diabetes Res Clin Pract 2011;91:1-12.

[97] Miller WR, Rollnick S. Motivational interviewing: preparing people for change. New York: The Guilford Press; 2002.

[98] Rollnick S, Miller WR, Butler CC. Motivational interviewing in health care: helping patients change behavior. New York: The Guilford Press; 2008.

[99] Abraham C, Michie S. A taxonomy of behavior change techniques used in interventions. Health Psychol 2008;27:379-87.

[100] Michie S, Abraham C. Interventions to change health behaviours: evidencebased or evidence-inspired. Psychology and Health 2004;19:29-39.

[101] Davidson KW, Goldstein M, Kaplan RM, Kaufmann PG, Knatterund GL, Orleans CT, et al. Evidence-based behavioral medicine: what is it and how do we achieve it. Ann Behav Med 2003;26:161-71.

[102] Katon W, Von Korff M, Lin E, Simon G. Rethinking practitioner roles in chronic illness: the specialist, primary care physician, and the practice nurse. Gen Hosp Psychiatry 2001;23:138-44.

[103] Doyle YG, Furey A, Flowers J. Sick individuals and sick populations: 20 years later. J Epidemiol Commun Health 2006;60:396-8.

[104] VWS. Beleidsdoelstellingen op het gebied van Volksgezondheid, Welzijn en Sport. Brief van de Minister van VWS. Policy objectives in the areas of Health, Welfare and Sport. Letter from the Minister Den Haag: VWS; 2011 [Min- isterie van Volksgezondheid, Welzijn en Sport].

[105] Prochaska JO, Velicer WF. The transtheoretical model of health behavior change. Am J Health Promot 1997;12:38-48.

[106] The Cochrane Collaboration. Cochrane handbook for systematic reviews of interventions. http://www.cochrane-handbook.org/; 30 January 2012. 
Noordman, J., Weijden, T. van der, Dulmen, S. van. Communication-related behavior change techniques used in face-to-face lifestyle interventions in primary care: a systematic review of the literature. Patient Education and Counseling: 2012, 89(2), 227-244

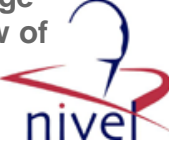

\section{TABLES}

Fig. 1. Flowchart of the inclusion procedure.

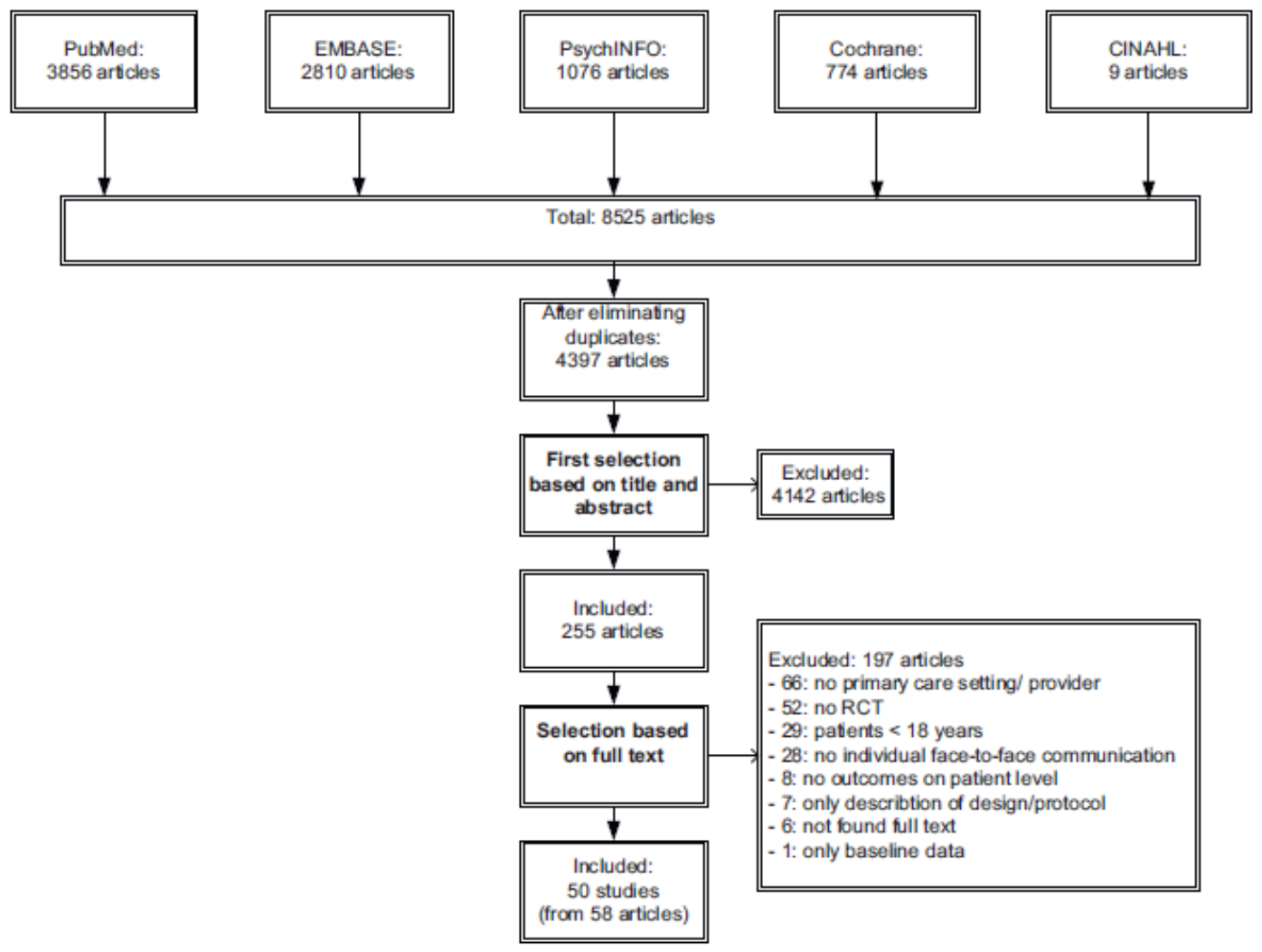


Noordman, J., Weijden, T. van der, Dulmen, S. van. Communication-related behavior change techniques used in face-to-face lifestyle interventions in primary care: a systematic review of the literature. Patient Education and Counseling: 2012, 89(2), 227-244

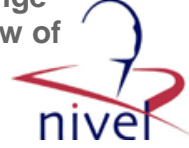

\begin{tabular}{|c|c|c|c|c|c|c|c|}
\hline No. & $\begin{array}{l}\text { Study: country; } \\
\text { quality; design }\end{array}$ & Population (patients) & $\begin{array}{l}\text { Health care } \\
\text { providers }\end{array}$ & Intervention group(s) & Control group & Type of lifestyle & $\begin{array}{l}\text { Primary/secondary } \\
\text { prevention or both }\end{array}$ \\
\hline 1 & $\begin{array}{l}\text { Aalto et al. [57]; } \\
\text { Finland; high } \\
\text { quality; RCT }\end{array}$ & $\begin{array}{l}118 \text { Early-phase heavy drinkers; no } \\
\text { men; aged between } 20 \text { and } 60 \text { years }\end{array}$ & $\begin{array}{l}41 \text { General } \\
\text { practitioners (GPs) } \\
\text { and } 15 \text { nurses from } \\
\text { five practices }\end{array}$ & $\begin{array}{l}\text { (1) Seven brief sessions by GP and } \\
\text { nurse consisting of RAMES } \\
\text { ingredients and self help pbooketet (2) } \\
\text { three brief sessions by GP consisting } \\
\text { of FAMES ingredients and self help } \\
\text { booklet }\end{array}$ & $\begin{array}{l}\text { Advised to reduce } \\
\text { drinking at baseline } \\
\text { and contact GP in } \\
\text { case of health } \\
\text { problem }\end{array}$ & Acohol & Primary prevention \\
\hline 2 & $\begin{array}{l}\text { Alterman et al. } \\
\text { [52]; USA; high } \\
\text { quality: RCT }\end{array}$ & $\begin{array}{l}240 \text { Smokers, who smoked at least } \\
\text { one pack of cigarettes daily: } 51.2 \% \\
\text { men in intervention group1 } 155 \% \text { men } \\
\text { in intervention group } 2,46.2 \% \text { men in } \\
\text { intervention group } 3 \text {; aged between } \\
21 \text { and } 65 \text { years }\end{array}$ & $\begin{array}{l}3 \text { Nurse } \\
\text { practitioners (NPs) }\end{array}$ & $\begin{array}{l}\text { (1) Low intensity: } 8 \text { weeks of NRT, } \\
1 \text { advice and education (AsE) session } \\
\text { with NP, (2) middle intensity: NRT } \\
\text { and } 4 \text { AsE sessions with NP., (3) high } \\
\text { intensity: NRT } 4 \text { ARE sessions with } \\
\text { NP, } 12 \text { weeks of individualized } \\
\text { cognitive behavioral therapy }\end{array}$ & - & Smoking & Primary prevention \\
\hline 3 & $\begin{array}{l}\text { Anderson et al. } \\
\text { [68]] USA; high } \\
\text { quality; RCT }\end{array}$ & $\begin{array}{l}874 \text { Inactive patients; } 54,8 \% \text { men; } \\
\text { aged between } 35 \text { and } 75 \text { years, free of } \\
\text { serious chronic disease, and not } \\
\text { found tohave apparent ischemia on a } \\
\text { screening treadmill test. }\end{array}$ & $\begin{array}{l}\text { Physicians and } \\
\text { health educators } \\
\text { from } 11 \text { practices }\end{array}$ & $\begin{array}{l}\text { (1) Advice only. (2) advice plus } \\
\text { behavioral counseling. ( } 3 \text { ) advice } \\
\text { plus behavioral counsel ing including } \\
\text { telephone contact and behavioral } \\
\text { classes }\end{array}$ & - & $\begin{array}{l}\text { Physical activity. } \\
\text { weight }\end{array}$ & Primary prevention \\
\hline 4 & $\begin{array}{l}\text { Armit et al. [421]; } \\
\text { Australia; high } \\
\text { quality; RCT }\end{array}$ & $\begin{array}{l}136 \text { nactive patients; } 40 \% \text { men; aged } \\
\text { between } 50 \text { and } 70 \text { years }\end{array}$ & $\begin{array}{l}10 \text { GPs and } 3 \\
\text { exercise scientists } \\
\text { (ES from 2 } \\
\text { practices }\end{array}$ & 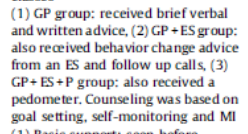 & - & Physical activity & Primary prevention \\
\hline 5 & $\begin{array}{l}\text { Aveyard et al. [53]; } \\
\text { UK; high quality; } \\
\text { RCT }\end{array}$ & $\begin{array}{l}925 \text { Smokers; } 47.3 \% \text { men in basic } \\
\text { support group, } 49.8 \% \text { men in weekly } \\
\text { support group; age } 18 \text { years or above }\end{array}$ & $\begin{array}{l}\text { Practice nurses } \\
\text { (PNs) from 26 } \\
\text { practices }\end{array}$ & $\begin{array}{l}\text { (1) Basic support: seen before } \\
\text { quitting, telephoned around quit day, } \\
\text { seen } 1 \text { and } 4 \text { weeks after the initial } \\
\text { appointment, } 15 \text { mg nicotine } \\
\text { patches, (2) weekly support: basic } \\
\text { support and telephone call at } 10 \text { days } \\
\text { and } 3 \text { weeks after the initial } \\
\text { appointment, additional visit at } 2 \\
\text { weeks, } 15 \mathrm{mg} \text { nicotine patches }\end{array}$ & - & Smoking & Primary prevention \\
\hline 6 & $\begin{array}{l}\text { Beckham [58]; } \\
\text { USA; lower quality: } \\
\text { RCT }\end{array}$ & $\begin{array}{l}29 \text { Hazardous drinkers in a low- } \\
\text { income rural area; } 46,4 \% \text { men; aged } \\
18 \text { years or older }\end{array}$ & NP & $\begin{array}{l}\text { One MI session with the NP } \\
(45-60 \text { min) }\end{array}$ & No intervention & Alcohol & Primary prevention \\
\hline 7 & $\begin{array}{l}\text { Beich et al. [59]; } \\
\text { Denmark; high } \\
\text { quality: RCT }\end{array}$ & $\begin{array}{l}906 \text { Risky drinkers; } 65.4 \% \text { men in } \\
\text { intervention group, } 68.5 \% \text { men in } \\
\text { control group; aged between } 18 \text { and } \\
64 \text { years }\end{array}$ & Phusicizns from 28 & $\begin{array}{l}\text { Brief counseling consisting of } \\
\text { FAMES ingredients based on the } \\
\text { 'drink-less' protocoli (WHO } \\
\text { collaborative study 2001) }\end{array}$ & No intervention & Alcohol & Primary prevention \\
\hline 8 & $\begin{array}{l}\text { Beresford et al. } \\
\text { [61]; USA; high } \\
\text { quality: RCT }\end{array}$ & $\begin{array}{l}2111 \text { Patients; } 31 \% \text { men in } \\
\text { intervention group, } 33 \% \text { men in } \\
\text { control group; age } 18 \text { years or above }\end{array}$ & $\begin{array}{l}\text { Physicians from } 28 \\
\text { practices (1-3 } \\
\text { from each practice })\end{array}$ & $\begin{array}{l}\text { Self-help booklet and a brief } \\
\text { motivational message }\end{array}$ & No intervention & Nutrition & Primary prevention \\
\hline 9 & $\begin{array}{l}\text { Bo et al. I72l: Italy: } \\
\text { high quality; RCT }\end{array}$ & $\begin{array}{l}375 \text { Dymetabolic patients; } 41.4 \% \\
\text { men in intervention group, } 42.2 \% \\
\text { men in control group; aged between } \\
45 \text { and } 64 \text { years }\end{array}$ & $\begin{array}{l}6 \text { Physicians and } 8 \\
\text { trained } \\
\text { professionals } \\
\text { (nutritionists, } \\
\text { specialists in } \\
\text { endocrinology, and } \\
\text { internal medicine). }\end{array}$ & $\begin{array}{l}\text { Detailed verbal and written } \\
\text { individualized recommendations } \\
\text { from trained professionals, } 5 \text { sessions } \\
\text { (minimal } 60 \text { min), the first a one-to- } \\
\text { one meeting, followed by group } \\
\text { sessions based on behavioral } \\
\text { counseling and focusing on practical } \\
\text { lifestyle tips }\end{array}$ & $\begin{array}{l}\text { Standard one time } \\
\text { unstructured } \\
\text { information given } \\
\text { by the physician }\end{array}$ & $\begin{array}{l}\text { Nutrition, physical } \\
\text { activity, weight }\end{array}$ & Primary prevention \\
\hline 10 & $\begin{array}{l}\text { Bolognesiet et. } \\
\text { |69): Italy, lower } \\
\text { quality; RCT }\end{array}$ & $\begin{array}{l}\text { 96 Overwweight or (severely) obese } \\
\text { patitents, } 46.9 \% \text { men; age between } 21 \\
\text { and } 70 \text { years }\end{array}$ & $8 \mathrm{GPS}$ & $\begin{array}{l}\text { Counseling (15min) with PACE } \\
\text { protocol based on stage of change of } \\
\text { the patient }\end{array}$ & $\begin{array}{l}\text { Usual care by GP } \\
\text { (15 min per visit) }\end{array}$ & $\begin{array}{l}\text { Physical activity, } \\
\text { weight }\end{array}$ & Primary prevention \\
\hline 11 & $\begin{array}{l}\text { Burton et al. [86]; } \\
\text { USA; lower quality; } \\
\text { RCT }\end{array}$ & $\begin{array}{l}4195 \text { Patients; } 37.3 \% \text { men in } \\
\text { intervention group, } 34.5 \% \text { men in } \\
\text { control group; aged } 65 \text { years of older }\end{array}$ & $\begin{array}{l}\text { Physicians from } \\
119 \text { practices/ } \\
\text { clinics }\end{array}$ & $\begin{array}{l}\text { Yearly preventive visits ( } 2 \text { years } s \text { and } \\
\text { optional counseling visits }\end{array}$ & $\begin{array}{l}\text { Mailed a pamphlet } \\
\text { describing good } \\
\text { health practices }\end{array}$ & $\begin{array}{l}\text { Smoking, alcohol, } \\
\text { physical activity }\end{array}$ & Primary prevention \\
\hline 12 & $\begin{array}{l}\text { Campbell et al. } \\
\text { [77]; UK; high } \\
\text { quality: RCT }\end{array}$ & $\begin{array}{l}1343 \text { Coronary patients, without } \\
\text { terminal illness or dementia and not } \\
\text { housebound; } 58.2 \% \text { men, age under } \\
80 \text { years (mean age } 66 \text { years). }\end{array}$ & $\begin{array}{l}19 \text { Clinics with } 28 \\
\text { nurses (PN, district } \\
\text { nurse, health } \\
\text { visitors) and GPs }\end{array}$ & $\begin{array}{l}\text { Advice, education, feedback, goal- } \\
\text { setting: Symptoms and treatment of } \\
\text { coronary heart disease reveviewed, use } \\
\text { of aspirin promoted, lifestyle } \\
\text { assessed, blood pressure and lipid } \\
\text { management reviewed. Follow-up: } \\
\text { according to clinical circumstances. }\end{array}$ & Usual care by GP & $\begin{array}{l}\text { Smoking, physical } \\
\text { activity, nutrition }\end{array}$ & $\begin{array}{l}\text { Secondary } \\
\text { prevention }\end{array}$ \\
\hline 13 & $\begin{array}{l}\text { Efraimsson et al. } \\
\text { [54]: Sweden; high } \\
\text { quality; RCT }\end{array}$ & $\begin{array}{l}52 \text { Patients with COPD: } 50 \% \text { men; } \\
\text { mean age in intervention group } 66 \\
\text { years, mean age in control group } 67 \\
\text { years }\end{array}$ & $\begin{array}{l}1 \text { Nurse from a } \\
\text { primary care dinic }\end{array}$ & $\begin{array}{l}\text { Standard care and two visits to a } \\
\text { nurse specialized in CopD care for } \\
\text { self-care education ( } 1 \mathrm{~h} \text { per session), } \\
\text { based on motivational dialog and } \\
\text { tailored to patient }\end{array}$ & $\begin{array}{l}\text { Usual care ( } 2 \text { visits } \\
\text { with 3-5 month } \\
\text { interval) }\end{array}$ & Smoking & $\begin{array}{l}\text { Secondary } \\
\text { prevention }\end{array}$ \\
\hline 14 & $\begin{array}{l}\text { Elley et al. [70]; } \\
\text { New Zealand; high } \\
\text { quality; RCT }\end{array}$ & $\begin{array}{l}878 \text { Sedentary patients; } 33 \% \text { men in } \\
\text { intervention group, } 34 \% \text { men in } \\
\text { control group; aged between } 40 \text { and } \\
79 \text { years }\end{array}$ & $\begin{array}{l}117 \text { GPs and PNs } \\
\text { from } 42 \text { practices } \\
\text { and exercise } \\
\text { spedalists (ES) }\end{array}$ & $\begin{array}{l}\text { GPs or PNs were prompted by patient } \\
\text { to give oral and written advica on } \\
\text { physical activity during usual } \\
\text { consultations ('Green prescription } \\
\text { programme', induding MM). ES } \\
\text { continued support by telephone and } \\
\text { post }\end{array}$ & Usual care by GP & $\begin{array}{l}\text { Physical activity. } \\
\text { weight }\end{array}$ & $\begin{array}{l}\text { Primary and } \\
\text { secondary } \\
\text { prevention }\end{array}$ \\
\hline 15 & $\begin{array}{l}\text { Grandes et al. [43]; } \\
\text { Spain; high quality; } \\
\text { RCT }\end{array}$ & $\begin{array}{l}\text { 4317 Sedentary patients; } 33.1 \% \text { men } \\
\text { in intervention group, } 35.8 \% \text { men in } \\
\text { control group; aged between } 20 \text { and } \\
80 \text { years }\end{array}$ & $\begin{array}{l}56 \text { Physicians from } \\
11 \text { practices }\end{array}$ & $\begin{array}{l}\text { Advice about physical activity and a } \\
\text { physical activity prescription (goal } \\
\text { setting to to the patients that attended } \\
\text { an additional appointment, including } \\
\text { self-monitoring }\end{array}$ & Usual care by GP & Physical activity & Primary prevention \\
\hline 16 & $\begin{array}{l}\text { Hollis et al. [37]: } \\
\text { USA; high quality: } \\
\text { RCT }\end{array}$ & $\begin{array}{l}3161 \mathrm{Smokers} ; 38.4 \% \text { men in control } \\
\text { group, } 40.2 \% \text { men in intervention } \\
\text { group } 1,44.1 \% \text { men in intervention } \\
\text { group2, } 4.1 . \% \text { in intervention } \\
\text { group } 3 \text {; age between } 18 \text { and } 70 \text { years }\end{array}$ & $\begin{array}{l}40 \text { Physicians and } \\
\text { nurse health } \\
\text { counselors }\end{array}$ & $\begin{array}{l}\text { Patient counseling: (1) self-quit } \\
\text { training assisted by nurse, (2) } \\
\text { recruitment to a group program } \\
\text { assisted by nurse, (3) combination } \\
\text { intervention assisted by nurse }\end{array}$ & $\begin{array}{l}\text { 30-s GP advice } \\
\text { message and a brief } \\
\text { pamphlet }\end{array}$ & Smoking & Primary prevention \\
\hline - & $\begin{array}{l}\text { Hollis et al. [55]; } \\
\text { USA; high quality: } \\
\text { RCT }\end{array}$ & See Hollis et al. [37] & $\begin{array}{l}42 \text { Physicians, } 7 \\
\text { physician } \\
\text { assistants, } 11 \text { NAt } \\
\text { and nurse health } \\
\text { counselors }\end{array}$ & See Hollis et al. [37] & See Hollis et al. [37] & See Hollis et al. [37] & See Hollis et al. [37] \\
\hline 17 & $\begin{array}{l}\text { Kastarinen et al. } \\
\text { [90]; Finl and; high } \\
\text { quality; RCT }\end{array}$ & $\begin{array}{l}715 \text { Hypertension patients (systolic } \\
\text { blood pressure } 140-149 \mathrm{~mm} H \mathrm{HG} \text { and } \\
\text { or diastolic blood pressure } 90- \\
109 \mathrm{~mm} H \mathrm{G} \text { or antihypertensive drug } \\
\text { treatment): } 48 \% \text { men in intervention } \\
\text { group, } 46 \% \text { men in control group; } \\
\text { aged between } 25 \text { and } 74 \text { years }\end{array}$ & $\begin{array}{l}\text { Nurses from } 10 \\
\text { practices }\end{array}$ & $\begin{array}{l}\text { Systematic health counseling given } \\
\text { by nurses for } 2 \text { years: targeting } \\
\text { weight, salt, alcohol and saturated fat } \\
\text { consumption reduction, increase in } \\
\text { physical activity. }\end{array}$ & $\begin{array}{l}\text { Usual care by GP } \\
\text { and nurse }\end{array}$ & $\begin{array}{l}\text { Weight, nutrition, } \\
\text { physical activity, } \\
\text { smoking, alcohol }\end{array}$ & Primary prevention \\
\hline 18 & $\begin{array}{l}\text { Kerse et al. [44]; } \\
\text { Australia; high } \\
\text { quality; RCr }\end{array}$ & $\begin{array}{l}267 \text { Patients; } 448 \% \text { men in } \\
\text { intervention group, } 48 \% \text { men in } \\
\text { control group; aged } 65 \text { years or older }\end{array}$ & $42 \mathrm{GPs}$ & $\begin{array}{l}\text { Health promotion advice based on an } \\
\text { educational programme, including } \\
\text { feedback }\end{array}$ & Usual care by GP & Physical activity & Primary prevention \\
\hline- & $\begin{array}{l}\text { Kerse et al. [71]; } \\
\text { New Zealand; high } \\
\text { quality; RCT }\end{array}$ & $\begin{array}{l}270 \text { Sedentary patient; } 37 \% \text { men; } \\
\text { age } 65 \text { years or older }\end{array}$ & See Elley et al. [70] & See Elley et al. [70] & See Eley et al. [70] & See Elley et al. [70] & See Bley et al. [70] \\
\hline 19 & $\begin{array}{l}\text { Ketola et al. [75]; } \\
\text { Finland; lower } \\
\text { quality; RCr }\end{array}$ & $\begin{array}{l}150 \text { Patients with existing } \\
\text { cardiovascular disease or multiple } \\
\text { riskf factorss } 48 \% \text { men; aged between } \\
33 \text { and } 65 \text { years }\end{array}$ & $\begin{array}{l}5 \text { CPSs, } 5 \text { nurses, } 1 \\
\text { dietician, } 1 \\
\text { physiotherapist }\end{array}$ & $\begin{array}{l}\text { Seen by GP and nurse at baseline, } 6 \text {, } \\
12 \text { and } 24 \text { months over two years. } \\
\text { Programme tailored to patient } \\
\text { accordingt to the riskfactor status and } \\
\text { needs. This could include bookdets of } \\
\text { healthy lifestyle habits, individual } \\
\text { dietary counseling by a nurse or a } \\
\text { dietician, joining a weight reduction } \\
\text { group, and physiotherapy } \\
\text { programme }\end{array}$ & $\begin{array}{l}\text { Standard care and a } \\
\text { bookket on healthy } \\
\text { lifesyle habits }\end{array}$ & $\begin{array}{l}\text { Weight, smoking, } \\
\text { physical activity }\end{array}$ & $\begin{array}{l}\text { Primary and } \\
\text { seccondary } \\
\text { prevention }\end{array}$ \\
\hline
\end{tabular}


Noordman, J., Weijden, T. van der, Dulmen, S. van. Communication-related behavior change techniques used in face-to-face lifestyle interventions in primary care: a systematic review of the literature. Patient Education and Counseling: 2012, 89(2), 227-244

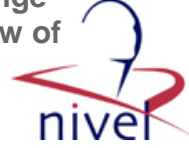

\begin{tabular}{|c|c|c|c|c|c|c|c|}
\hline №. & $\begin{array}{l}\text { Study; country; } \\
\text { quality: design }\end{array}$ & Population (patients) & $\begin{array}{l}\text { Health care } \\
\text { providers }\end{array}$ & Intervention group(s) & Control group & Type of lifestyle & $\begin{array}{l}\text { Primary /secondary } \\
\text { prevention or botha }\end{array}$ \\
\hline 20 & $\begin{array}{l}\text { Kinmonth et al. } \\
\text { [82]: } \\
\text { quality; RCT }\end{array}$ & $\begin{array}{l}360 \text { Diabetic patients: } 59 \% \text { men in } \\
\text { intervention group, } 60 \% \text { men in } \\
\text { control group; age between } 30 \text { and } \\
70 \text { years }\end{array}$ & $\begin{array}{l}43 \text { GPs and } 64 \text { PNs } \\
\text { from } 41 \text { practices }\end{array}$ & $\begin{array}{l}\text { Routine care plus additional training } \\
\text { of doctors and nurses, based on } \\
\text { patient-centered care and a patient } \\
\text { held bookdet encouraging questions }\end{array}$ & $\begin{array}{l}\text { Usual care by G.P } \\
\text { and nurse }\end{array}$ & $\begin{array}{l}\text { Weight, nutrition, } \\
\text { physical activity. } \\
\text { smoking }\end{array}$ & $\begin{array}{l}\text { Secondary } \\
\text { prevention }\end{array}$ \\
\hline 21 & $\begin{array}{l}\text { Koelewijn-van } \\
\text { Loon et al. [87]: } \\
\text { Netherlands; high } \\
\text { quality; RCT }\end{array}$ & $\begin{array}{l}615 \text { Patients with risk at } \\
\text { cardiovascular disease; } 45 \% \text { men; age } \\
18 \text { years or above (mean age } 57 \\
\text { years) }\end{array}$ & $\begin{array}{l}24 \text { PNs and GPs } \\
\text { from } 25 \text { practices }\end{array}$ & $\begin{array}{l}\text { Nurse-led cardiovascular risk } \\
\text { management, including riks } \\
\text { assessment, risk communication, a } \\
\text { decision aid and adapted } \\
\text { motivational interviewing }\end{array}$ & $\begin{array}{l}\text { Minimal nurse-led } \\
\text { intervention }\end{array}$ & $\begin{array}{l}\text { Smoking, alcohol, } \\
\text { nutrition, physical } \\
\text { activity }\end{array}$ & $\begin{array}{l}\text { Primary and } \\
\text { secondary } \\
\text { prevention }\end{array}$ \\
\hline- & $\begin{array}{l}\text { Koelewijn-van } \\
\text { Loon et al. [381: } \\
\text { Netherlands; high } \\
\text { quality; RCT }\end{array}$ & See Koelewijn-van Loon et al. [87] & $\begin{array}{l}\text { See Koelew wijn-van } \\
\text { Loon et al. [87] }\end{array}$ & See Koelewijn-van Loon et al. [87] & $\begin{array}{l}\text { See Koelewijin-van } \\
\text { Loon et al. }[87]\end{array}$ & $\begin{array}{l}\text { See Koelewijn-van } \\
\text { Loon et al. }[87]\end{array}$ & $\begin{array}{l}\text { See Koelewijin-van } \\
\text { Loon et al. }[87]\end{array}$ \\
\hline 22 & $\begin{array}{l}\text { Lancaster et al. } \\
\text { [56]; : U: high } \\
\text { quality; RCT }\end{array}$ & $\begin{array}{l}497 \text { Smokers; } 44.6 \% \text { men in } \\
\text { intervention group1,51.6\% men in } \\
\text { intervention group2; aged } 18 \text { years } \\
\text { or above }\end{array}$ & $\begin{array}{l}\text { GABs and PNs from } 6 \\
\text { practices }\end{array}$ & $\begin{array}{l}\text { (1) Brief verbal or written advice } \\
\text { from a GP plus extended counseling } \\
\text { and follow-up from a trained PN, (2) } \\
\text { brief advice from a GP alone }\end{array}$ & - & Smoling & Primary prevention \\
\hline 23 & $\begin{array}{l}\text { Lauritzen et al. } \\
\text { |911: Denmark: } \\
\text { lower quality; RCT }\end{array}$ & $\begin{array}{l}1507 \text { Patients; } 48.76 \text { men; aged } \\
\text { between } 30 \text { and } 49 \text { years }\end{array}$ & $\begin{array}{l}9 \text { GPs from } 4 \\
\text { practices }\end{array}$ & $\begin{array}{l}\text { (1) Group having questionnaires, a } \\
\text { broad heal th test with written advice } \\
\text { followed by a normal 10-15 min } \\
\text { consultation on demand, (2) same as } \\
\text { intervention group } 1 \text {, but with a } \\
\text { planned } 45 \text { min patient-centered } \\
\text { consultation }\end{array}$ & $\begin{array}{l}\text { Control group } \\
\text { answering } \\
\text { questionnaires }\end{array}$ & $\begin{array}{l}\text { Smoking, weight, } \\
\text { al ohol, nutrition, } \\
\text { physical activivy }\end{array}$ & Primary prevention \\
\hline 24 & $\begin{array}{l}\text { Lawton et al. [45]; } \\
\text { New Z Zaland; high } \\
\text { quality; RCT }\end{array}$ & $\begin{array}{l}1089 \text { Physical inactive patients; no } \\
\text { men; aged between } 40 \text { and } 74 \text { years }\end{array}$ & $\begin{array}{l}\text { G.PS and PNs from } \\
17 \text { practices }\end{array}$ & $\begin{array}{l}\text { The green prescription': briefly } \\
\text { counsel ( } 713 \text { min) patients using MI } \\
\text { tednniques to increase physical } \\
\text { activity, six month follow-up visit } \\
\text { and monthly telephone support over } \\
\text { nine months }\end{array}$ & $\begin{array}{l}\text { Usual care by GP } \\
\text { and PN }\end{array}$ & Physical activity & Primary prevention \\
\hline 25 & $\begin{array}{l}\text { Lear et al. [83]; } \\
\text { Canada; high } \\
\text { quality; RCT }\end{array}$ & $\begin{array}{l}302 \text { Patients with ischemic heart } \\
\text { disease; } 83 \% \text { men in intervention } \\
\text { group, } 82 \% \text { men in control group; } \\
\text { mean age } 64.8 \text { year in intervention } \\
\text { group, mean age } 63.4 \text { year in control } \\
\text { group }\end{array}$ & $\begin{array}{l}\text { Physidians and case } \\
\text { manager (dietician } \\
\text { or exercise } \\
\text { specialist if } \\
\text { necessary) }\end{array}$ & $\begin{array}{l}\text { Exercise sessions, telephone follow- } \\
\text { ups, lifestyle and risk factor } \\
\text { ounseling sessions, and reports to } \\
\text { the participants' family physicians }\end{array}$ & Usual care by GP & $\begin{array}{l}\text { Physical activity, } \\
\text { nutrition, weight, } \\
\text { smoking }\end{array}$ & $\begin{array}{l}\text { Secondary } \\
\text { prevention }\end{array}$ \\
\hline 26 & $\begin{array}{l}\text { Lee et al. [46]; } \\
\text { Taiwan; high } \\
\text { quality; RCT }\end{array}$ & $\begin{array}{l}202 \text { Patients with mild to moderate } \\
\text { hypertension; } 62.7 \% \text { men in } \\
\text { intervention group. } 54 \% \text { men in } \\
\text { control group; aged 60years and over }\end{array}$ & $\begin{array}{l}\text { Public health nurse } \\
\text { and doctors }\end{array}$ & $\begin{array}{l}\text { Six-month community-based } \\
\text { wall king intervention based on self- } \\
\text { efficacy theory, nurse provided both } \\
\text { face-to-face and telephone } \\
\text { behavioral support designed to assist } \\
\text { participants to increase their walking }\end{array}$ & $\begin{array}{l}\text { Usual care by GP } \\
\text { and/or nurse }\end{array}$ & Physical activity & Primary prevention \\
\hline 27 & $\begin{array}{l}\text { Little et al. [47]; } \\
\text { UK: high quality; } \\
\text { RCT }\end{array}$ & $\begin{array}{l}152 \text { Sedentary patients with risk at } \\
\text { cardiovascular disease; } 45.6 \% \text { men in } \\
\text { intervention group } 1.41 .4 \% \text { men in } \\
\text { interention group } 2,46.6 \% \text { men in } \\
\text { intervention ngroup } 3.44 .3 \% \text { men in } \\
\text { control groups; aged } 18 \text { years or } \\
\text { older }\end{array}$ & $\begin{array}{l}\text { GPAs and PNs from } 4 \\
\text { practices }\end{array}$ & 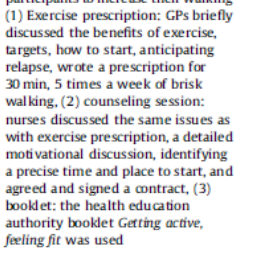 & $\begin{array}{l}\text { Control group for } \\
\text { each intervention } \\
\text { (no G G vs G. GP, no } \\
\text { nurse vs. nurse, no } \\
\text { booklet vu, sooklet } \\
\text { or combination of } \\
\text { interventions) }\end{array}$ & Physical activity & Primary prevention \\
\hline 28 & $\begin{array}{l}\text { Logue et al. [73]: } \\
\text { USA; high quality; } \\
\text { RCT }\end{array}$ & $\begin{array}{l}665 \text { Obese or overweight patients; } \\
33 \% \text { men in intervention group 1,30\% } \\
\text { men in intervention groupp } 2 \text {; aged } \\
\text { between } 40 \text { and } 69 \text { years }\end{array}$ & $\begin{array}{l}\text { Physicians from } 15 \\
\text { practices, dietician } \\
\text { and weight loss } \\
\text { advisor }\end{array}$ & 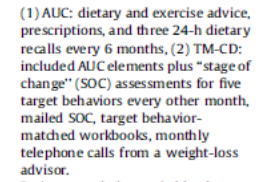 & - & $\begin{array}{l}\text { Weight, physical } \\
\text { activity, nutrition }\end{array}$ & Primary prevention \\
\hline 29 & $\begin{array}{l}\text { McManus et al. } \\
\text { [85]; UK; high } \\
\text { quality; RCT }\end{array}$ & $\begin{array}{l}400 \text { Patients; } 47 \% \text { men, age between } \\
35 \text { and } 75 \text { years }\end{array}$ & GPs and PNs & $\begin{array}{l}\text { Patients used electronic blood } \\
\text { pressurem machines (self-monitoring), } \\
\text { reecived card with blood pressure } \\
\text { target and advicic to visist GP or or if if } \\
\text { pressure was above target (feedback) }\end{array}$ & $\begin{array}{l}\text { Information sheet } \\
\text { on self help } \\
\text { measures to lower } \\
\text { blood pressure }\end{array}$ & $\begin{array}{l}\text { Smoking, alcohol, } \\
\text { physical activity, } \\
\text { weight }\end{array}$ & Primary prevention \\
\hline 30 & $\begin{array}{l}\text { Munoz et al. [84]; } \\
\text { Spain: lower } \\
\text { quality: RCT }\end{array}$ & $\begin{array}{l}983 \text { Coronary patients; } 75 \% \text { men; age } \\
\text { between } 30 \text { and } 75 \text { years }\end{array}$ & $\begin{array}{l}23 \text { Practices with } \\
\text { more than } 200 \text { GPS }\end{array}$ & $\begin{array}{l}\text { GPS followed guidelines on } \\
\text { cardiovascular prevention, } \\
\text { recomment healthy lifestyle, } \\
\text { measuring blod pressure, weight, } \\
\text { adjusting treatment and mediction }\end{array}$ & Usual care by GP. & $\begin{array}{l}\text { Smoking, physical } \\
\text { activity, nutrition } \\
\text { (Mediterranean } \\
\text { diet), weight }\end{array}$ & $\begin{array}{l}\text { Secondary } \\
\text { prevention }\end{array}$ \\
\hline - & $\begin{array}{l}\text { Murchie et al. [78]; } \\
\text { UK; high quality: } \\
\text { RCT }\end{array}$ & See Campbell et al. [77] & $\begin{array}{l}\text { See Campbell et al. } \\
{[77]}\end{array}$ & See Campbell et al. [77] & $\begin{array}{l}\text { See Campbell et al. } \\
{[77] \text {. }}\end{array}$ & $\begin{array}{l}\text { See Campbell et al. } \\
{[77]}\end{array}$ & $\begin{array}{l}\text { See Campbell et al. } \\
{[77]}\end{array}$ \\
\hline - & $\begin{array}{l}\text { Murchie et al. [79]: } \\
\text { UK; high quality: } \\
\text { RCT }\end{array}$ & See Campbell et al. [77] & $\begin{array}{l}\text { See Campbell et al. } \\
{[77]}\end{array}$ & See Campbell et al. [77] & $\begin{array}{l}\text { See Campbell et al. } \\
{[77]}\end{array}$ & $\begin{array}{l}\text { See Campbell et al. } \\
\text { [77] }\end{array}$ & $\begin{array}{l}\text { See Campbell et al. } \\
\text { [77] }\end{array}$ \\
\hline 31 & $\begin{array}{l}\text { Noknoy et al. [39]; } \\
\text { Thailand; high } \\
\text { quality; RCT }\end{array}$ & $\begin{array}{l}117 \text { Hazardous drinkers; } 91 \% \text { male; } \\
\text { age between } 18 \text { and } 65 \text { years }\end{array}$ & $\begin{array}{l}\text { Nurses in } 8 \\
\text { practices }\end{array}$ & $\begin{array}{l}\text { Three } 15 \text { min counseling sessions: } \\
\text { motivation to change (MI) according } \\
\text { to stage of change on day } 1 \text {, at } 2 \text { and } 6 \\
\text { weeks. }\end{array}$ & $\begin{array}{l}\text { Patients completed } \\
\text { research } \\
\text { assessment only }\end{array}$ & Acohol & Primary prevention \\
\hline 32 & $\begin{array}{l}\text { Pritchard etal. [92]; } \\
\text { Australia; high } \\
\text { quality; RCT }\end{array}$ & $\begin{array}{l}273 \text { Patients with hypertension and/ } \\
\text { or diabetes type } 2 \text { and/or } \\
\text { overweight, } 28 \% \text { men, age between } \\
25 \text { and } 65 \text { years }\end{array}$ & GPs and dieticians & $\begin{array}{l}\text { (1) Dietician group: } 6 \text { individual } \\
\text { counseling sessions spaced equally } \\
\text { over } 212 \text { months, focusing on } \\
\text { nutrition and exercise (first } 45 \text { min, } \\
\text { next } 15 \text { min by dietician, (2) doctor/ } / \\
\text { dietician group same sas group 1, but } \\
\text { doctor invited patients to the study } \\
\text { and reviewed progress at } 2 \text { of the } 6 \\
\text { sessions (5min) }\end{array}$ & $\begin{array}{l}\text { Control group } \\
\text { received results of } \\
\text { initial } \\
\text { measurements and } \\
\text { if they had queries } \\
\text { were advised to } \\
\text { discuss these with } \\
\text { whom they had } \\
\text { made an } \\
\text { appointment }\end{array}$ & $\begin{array}{l}\text { Weight, nutrition, } \\
\text { physical activity, } \\
\text { smoking, alcohol }\end{array}$ & $\begin{array}{l}\text { Primary and } \\
\text { secondary } \\
\text { prevention }\end{array}$ \\
\hline 33 & $\begin{array}{l}\text { Ramos et al. [40]; } \\
\text { Spain; high quality; } \\
\text { RCT }\end{array}$ & $\begin{array}{l}287 \text { Smokers who were in the } \\
\text { preparatovy phase; } 46 \% \text { men; mean } \\
\text { age } 45 \text { years }\end{array}$ & $\begin{array}{l}\text { Physicians and } \\
\text { nurses from } 10 \\
\text { practices }\end{array}$ & $\begin{array}{l}\text { (1) Intensive group: cunseling. } \\
\text { psychological support based on ML. } \\
\text { Follow-up sessions, pharmacological } \\
\text { treatment, (2) intensive individual: } \\
\text { counseling, psychological support } \\
\text { based on ML. } 5 \text { Follow-up sessions, } \\
\text { pharmacological treatment }\end{array}$ & $\begin{array}{l}\text { Minimal: } \\
\text { pharmacological } \\
\text { treatment, basic MI } \\
\text { counseling }\end{array}$ & $\begin{array}{l}\text { Smoking (also } \\
\text { baseline data on } \\
\text { alcohol, physical } \\
\text { activity and } \\
\text { nutrition) }\end{array}$ & Primary prevention \\
\hline 34 & $\begin{array}{l}\text { Reed et al. [48]; } \\
\text { USA; lower quality: } \\
\text { RCT }\end{array}$ & 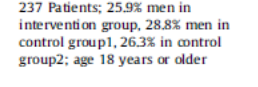 & $\begin{array}{l}12 \text { Physicians, } 4 \\
\text { nurses and } 1 \mathrm{NP}\end{array}$ & $\begin{array}{l}\text { Counseling (using "As" As" method) } \\
\text { and educational map (with } \\
\text { geographic information of all } \\
\text { requational facilities within } 2 \text { mile } \\
\text { radius) }\end{array}$ & $\begin{array}{l}\text { (1) Counseling only } \\
\text { group, (2) standard } \\
\text { care }\end{array}$ & Physical activity & Primary prevention \\
\hline 35 & $\begin{array}{l}\text { Reid et al. [65]: } \\
\text { Australia; high } \\
\text { quality; RCT }\end{array}$ & $\begin{array}{l}45 \text { Patients with history of } \\
\text { hypertension; } 43 \% \text { men in } \\
\text { withdrawal group, 5o\% men in } \\
\text { continued group; age between } 18 \\
\text { and } 60 \text { years }\end{array}$ & $13 \mathrm{GPS}$ & $\begin{array}{l}\text { (1) Continued medication: } \\
\text { medication, counseling regarding } \\
\text { lifestyle change, self-help material, } \\
\text { (2) Withdrawal: medication stop } \\
\text { over 2-week period, counseling } \\
\text { regarding lifestyle change, self-help } \\
\text { material }\end{array}$ & - & $\begin{array}{l}\text { Physical activity. } \\
\text { nutrition }\end{array}$ & Primary prevention \\
\hline
\end{tabular}


Noordman, J., Weijden, T. van der, Dulmen, S. van. Communication-related behavior change techniques used in face-to-face lifestyle interventions in primary care: a systematic review of the literature. Patient Education and Counseling: 2012, 89(2), 227-244

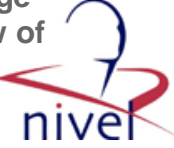

\begin{tabular}{|c|c|c|c|c|c|c|c|}
\hline No. & $\begin{array}{l}\text { Study; country; } \\
\text { quality; designn }\end{array}$ & Population (patients) & $\begin{array}{l}\text { Health care } \\
\text { providers }\end{array}$ & Intervention group(s) & Control group & Type of lifestyle & $\begin{array}{l}\text { Primary/secondary } \\
\text { prevention or both }{ }^{2}\end{array}$ \\
\hline 36 & $\begin{array}{l}\text { Rubak et al. [88]; } \\
\text { Denmark; high } \\
\text { quality; RCT }\end{array}$ & $\begin{array}{l}265 \text { Diabetic patients; age between } \\
40 \text { and } 69 \text { years }\end{array}$ & $65 \mathrm{GPs}$ & $\begin{array}{l}\text { G.Ps received a motivational } \\
\text { interviewing (MI) course }\end{array}$ & $\begin{array}{l}\text { GPs not receiving a } \\
\text { Ml course }\end{array}$ & $\begin{array}{l}\text { Smoking, alcohol, } \\
\text { nutrition, physical } \\
\text { activity }\end{array}$ & $\begin{array}{l}\text { Secondary } \\
\text { prevention }\end{array}$ \\
\hline 37 & $\begin{array}{l}\text { Rubio et al. [41]; } \\
\text { Spain; high quality: } \\
\text { RCT }\end{array}$ & $\begin{array}{l}752 \text { Binge drinkers; } 65 \% \text { men; age } \\
\text { between } 18 \text { and } 65 \text { years }\end{array}$ & $\begin{array}{l}74 \text { Family } \\
\text { physicians and } \\
\text { office nurses }\end{array}$ & $\begin{array}{l}\text { Brief intervention: } 2 \text { short counseling } \\
\text { sessions } 4 \text { weeks apart ( } 10-15 \mathrm{~min}) \text {. } \\
\text { physicians used script workbook. } 2 \\
\text { follow-up sessions by nurse }\end{array}$ & $\begin{array}{l}\text { Patients received a } \\
\text { bookket on general } \\
\text { health issues and } \\
\text { were fol loweded-up } \\
\text { at } 6,12 \text { months }\end{array}$ & & Primary prevention \\
\hline 38 & $\begin{array}{l}\text { Sacerdote et al. } \\
\text { [6]6]: Italy, high } \\
\text { quality; RCT }\end{array}$ & $\begin{array}{l}3186 \text { Patients who were not obese or } \\
\text { affected by chronic or severe } \\
\text { diseases; } 500 \text { men; age between } 18 \\
\text { and } 65 \text { years }\end{array}$ & 33 GPs & $\begin{array}{l}\text { Educational personalized } \\
\text { intervention and brochure on basic } \\
\text { healthy diet based on Italian } \\
\text { guidedines for correct nutrition. } \\
\text { Follow-up advice every } 6 \text { months }\end{array}$ & $\begin{array}{l}\text { A similar and non- } \\
\text { personalized } \\
\text { conversation } \\
\text { without the use of a } \\
\text { brochure }\end{array}$ & Nutrition, weight & Primary prevention \\
\hline 39 & $\begin{array}{l}\text { Schaus et al. [60]; } \\
\text { USA; lower quality; } \\
\text { RCT }\end{array}$ & $\begin{array}{l}363 \text { High-risk drinking students; } 48 \% \\
\text { men; age } 18 \text { years and older (mean } \\
\text { age } 20.6 \text { years) }\end{array}$ & $\begin{array}{l}\text { Primary care } \\
\text { providers } \\
\text { (intervention: } 2 \\
\text { physicians, } 1 \\
\text { physician's } \\
\text { assistant, } 1 \mathrm{NP} \text { ) }\end{array}$ & $\begin{array}{l}2 \text { Brief sessions based on MI } \\
\text { techniques and cognitive behavioral } \\
\text { skills training ( } 20 \mathrm{~min})\end{array}$ & $\begin{array}{l}\text { Participants were } \\
\text { assigned to } \\
\text { university health } \\
\text { services providers } \\
\text { who received no } \\
\text { training in the MI } \\
\text { protocol }\end{array}$ & Alcohol & Primary prevention \\
\hline 40 & $\begin{array}{l}\text { Spink et al. [49]; } \\
\text { Canada; high } \\
\text { quality; RCT }\end{array}$ & $\begin{array}{l}90 \text { Patients who were regularly } \\
\text { active, but were thinking about } \\
\text { inceasing their ativity level } \\
\text { ("contemplators'); } 17 \% \text { male in } \\
\text { interention group 1, } 19 \% \text { male in } \\
\text { intervention group } 2 \text {; age } 18 \text { or older } \\
\text { (mean age } 43 \text { year) }\end{array}$ & 24 Physicians & $\begin{array}{l}\text { (1) Counseling: physician-directed- } \\
\text { modified PACE protocol, (2) } \\
\text { Enhanced counseling: physician- } \\
\text { directed-modified PACE protocol and } \\
\text { telephone counseling }\end{array}$ & & Physical activity & Primary prevention \\
\hline 41 & $\begin{array}{l}\text { Steptoe et al. [80]; } \\
\text { UK; lower quality; } \\
\text { RCT }\end{array}$ & $\begin{array}{l}\text { 883 Patients with inceased risk of } \\
\text { coronary heart disease (regular } \\
\text { cigarette smoking high serum } \\
\text { cholesterol concentration and/or } \\
\text { high body massinindexcombined with } \\
\text { low physical activity); } 46 \% \text { men; } \\
\text { mean age } 46.7 \text { years }\end{array}$ & $\begin{array}{l}\text { PNs in } 20 \text { practices } \\
\text { (one PN in each of } \\
\text { the } 10 \text { intervention } \\
\text { proartices was } \\
\text { trained) }\end{array}$ & $\begin{array}{l}\text { Brief behavioral counseling based on } \\
\text { stage of change model to reduce } \\
\text { smoking, dietary fat intake and } \\
\text { increase physical activity. Patients } \\
\text { with } 2 \text { risk factors invited for } 3 \\
\text { sessions, with } 1 \text { risk factor for } 2 \\
\text { sessions (20 min per session). In } \\
\text { between trlephone counseling. }\end{array}$ & Usual care by PN & $\begin{array}{l}\text { Smoking, nutrition, } \\
\text { physical activity, }\end{array}$ & Primary prevention \\
\hline - & $\begin{array}{l}\text { Steptoe et al. [62]; } \\
\text { UK; lower quality; } \\
\text { RCT }\end{array}$ & $\begin{array}{l}365 \text { Patients with elevated } \\
\text { cholesterol; } 49 \% \text { men; mean age } 52.1 \\
\text { years }\end{array}$ & $\begin{array}{l}\text { See Steptoe et al. } \\
{[80]}\end{array}$ & $\begin{array}{l}\text { Brief behavioral counseling based on } \\
\text { stage of change model to reduce } \\
\text { dietaryfatan intake. Patients with } 2 \text { risk } \\
\text { factors invited for } 3 \text { sessions, with } 1 \\
\text { risk factor for } 2 \text { sessions (20 min per } \\
\text { session) In between telephone } \\
\text { counseling }\end{array}$ & $\begin{array}{l}\text { See Steptoe et al. } \\
{[80]}\end{array}$ & Nutrition & Primary prevention \\
\hline - & $\begin{array}{l}\text { Steptoe et al. [81]; } \\
\text { UK; lower quality; } \\
\text { RCT }\end{array}$ & See Steptoe et al. [80] & $\begin{array}{l}\text { See Steptoe et al. } \\
{[80]}\end{array}$ & See Steptoe et al. [80] & $\begin{array}{l}\text { See Steptoe et al. } \\
{[80]}\end{array}$ & $\begin{array}{l}\text { See Steptoe et al. } \\
{[80]}\end{array}$ & $\begin{array}{l}\text { See Steptoe et al. } \\
{[80]}\end{array}$ \\
\hline 42 & $\begin{array}{l}\text { Steptoe et al. [63]: } \\
\text { UK; high quality: } \\
\text { RCT }\end{array}$ & $\begin{array}{l}271 \text { Patients from a low income and } \\
\text { ethnically mixed population; } 39 \% \\
\text { men; aged between } 18 \text { and } 70 \text { years } \\
\text { (mean age } 43 \text { year) }\end{array}$ & $\begin{array}{l}\text { Nurses from one } \\
\text { practice in an } \\
\text { deppived inner ciry } \\
\text { area }\end{array}$ & $\begin{array}{l}\text { (1) Brief individual behavioral } \\
\text { counseling based on stage of change } \\
\text { model (15 min), (2) time matched } \\
\text { nutrition education counseling } \\
\text { (15min) }\end{array}$ & - & Nutrition & Ptimary prevention \\
\hline 43 & $\begin{array}{l}\text { Swinburn et al. } \\
\text { [50): New Zeal and; } \\
\text { high quality: RCT }\end{array}$ & $\begin{array}{l}456 \text { Sedentary patients; } 41 \% \text { men in } \\
\text { intervention group } 1,366 \text { in } \\
\text { intervention group } 2 ; \text { mean age } 49 \\
\text { years }\end{array}$ & $\begin{array}{l}37 \text { GPs in two } \\
\text { practices }\end{array}$ & $\begin{array}{l}\text { (1) Verbal advice }+ \text { written advice } \\
\text { (education), (2) verbal advice only }\end{array}$ & - & Physical activity & Primary prevention \\
\hline 44 & $\begin{array}{l}\text { Ter Bogt et al. [64]: } \\
\text { Netherlands; lower } \\
\text { quality: RCT }\end{array}$ & $\begin{array}{l}457 \text { Overweight or obese patients } \\
\text { with hypertension and/or } \\
\text { dyslipidemia; } 48 \% \text { men; mean age } 56 \\
\text { years }\end{array}$ & $\begin{array}{l}\text { NPs and GPs from } \\
11 \text { practices } \\
\text { (varying from } 1 \text { to } 7 \\
\text { G.Fs and } 1 \text { to } 3 \text { NPs } \\
\text { per location) }\end{array}$ & $\begin{array}{l}4 \text { Individual visits to NP and one } \\
\text { feeddack session by telephone for } \\
\text { lifestyle counseling with guidance of } \\
\text { NP using a standardized } \\
\text { computerized software program }\end{array}$ & Usual care by GPP & Weight & Primary prevention \\
\hline 45 & $\begin{array}{l}\text { Tonstad et al. [89]; } \\
\text { Norway; lower } \\
\text { quality; RCT }\end{array}$ & $\begin{array}{l}51 \text { Patients with hypertension; 67.7\% } \\
\text { men in intervention group, 83.3\% } \\
\text { men in control group; aged 30-69 } \\
\text { years }\end{array}$ & 1 Nurse, physicians & $\begin{array}{l}\text { Nurse-led lifestyle counseling based } \\
\text { on stages of change: monthly for } 6 \\
\text { months (first } 60 \text { min, next sessions } \\
30 \text { min) }\end{array}$ & $\begin{array}{l}\text { Brief advice, } \\
\text { recommended to } \\
\text { visit their physician } \\
\text { for care during the } \\
\text { study and recalled } \\
\text { for the final } \\
\text { eval uation after } 6 \\
\text { months }\end{array}$ & $\begin{array}{l}\text { Smoking, nutrition, } \\
\text { physical activity, } \\
\text { alcohol }\end{array}$ & Primary prevention \\
\hline 46 & $\begin{array}{l}\text { Van den Bemt et al. } \\
\text { [766; Netherlands; } \\
\text { high quality; RCT }\end{array}$ & $\begin{array}{l}189 \text { Patients with COPD; } 56 \% \text { men in } \\
\text { intervention group, } 47 \% \text { men in } \\
\text { control group; age } 25 \text { years or older }\end{array}$ & $\begin{array}{l}\text { GPs from } 34 \\
\text { practices } \\
\text { respiratory experts } \\
\text { and lung function } \\
\text { technicians }\end{array}$ & $\begin{array}{l}\text { Ongoing monitoring of COPD } \\
\text { patients with respiratory expert } \\
\text { recommendations (feedbadk) for GP. }\end{array}$ & $\begin{array}{l}\text { Usual care, with } \\
\text { spiromertry at } \\
\text { baseline and } 2 \\
\text { years }\end{array}$ & $\begin{array}{l}\text { Weight, smoking, } \\
\text { physical activity }\end{array}$ & $\begin{array}{l}\text { Secondary } \\
\text { prevention }\end{array}$ \\
\hline 47 & $\begin{array}{l}\text { Van Sluijs et al. } \\
\text { [51]: Netherlands; } \\
\text { high quality; RCT }\end{array}$ & $\begin{array}{l}358 \text { Patients diagnosed with } \\
\text { hypertension, hyperdolesterolemia } \\
\text { andlor non-insulin-dependent } \\
\text { diabetes and not in the maintenance } \\
\text { stage for regular physical activity; } \\
50.8 \% \text { men; aged between } 18 \text { and } 70 \\
\text { years (mean age } 55.5 \text { years) }\end{array}$ & 29 GPs & $\begin{array}{l}2 \text { Visits with GP and } 2 \text { telephone } \\
\text { booster calls by a physical activity } \\
\text { counselor: both using PACE physical } \\
\text { activity program. }\end{array}$ & $\begin{array}{l}10 \text { min session at } \\
\text { baseline by GP. }\end{array}$ & Physical activity & $\begin{array}{l}\text { Primary and } \\
\text { secondary } \\
\text { prevention }\end{array}$ \\
\hline 48 & $\begin{array}{l}\text { Whittemore et al. } \\
\text { [74]: USA; lower } \\
\text { quality; RCT }\end{array}$ & $\begin{array}{l}58 \text { Patients at risk for diabetes type } 2, \\
\text { metabolic syndrome or impaired } \\
\text { glucose tolerance (IGT), moderately } \\
\text { low-income sample; } 8 \% \text { men; age } 21 \\
\text { years or above }\end{array}$ & $\begin{array}{l}7 \text { NPs from } 4 \\
\text { practices, } 1 \\
\text { nutritionist }\end{array}$ & $\begin{array}{l}\text { Lifestyle change program: culturally } \\
\text { relevant education on nutrition, } \\
\text { exercise and diabetes type } 2 \\
\text { prevention, behavioral support in } \\
\text { identifying lifestyle change goals and } \\
\text { barriers, MI when partidpants were } \\
\text { unable to achieve lifestrtye goalse }\end{array}$ & $\begin{array}{l}\text { Enhanced standard } \\
\text { care program }\end{array}$ & $\begin{array}{l}\text { Nutrition, weight, } \\
\text { physical activity }\end{array}$ & Primary prevention \\
\hline 49 & $\begin{array}{l}\text { Willaing et al. [67]: } \\
\text { Denmark, high } \\
\text { quality; RCr }\end{array}$ & $\begin{array}{l}503 \text { Patients with high BML, } \\
\text { dyslipidemia and/or type } 2 \text { diabetes; } \\
29 \% \text { men in dietician group, } 34 \% \text { men } \\
\text { in GP group; age } 18 \text { years or older }\end{array}$ & $\begin{array}{l}60 \text { GPs and } 2 \\
\text { dieticians }\end{array}$ & 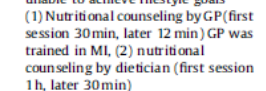 & - & Nutrition, weight & $\begin{array}{l}\text { Primary and } \\
\text { secondary } \\
\text { prevention }\end{array}$ \\
\hline 50 & $\begin{array}{l}\text { Woollard et al. } \\
\text { [94]; Australia; } \\
\text { lower quality: RCT }\end{array}$ & $\begin{array}{l}212 \text { Patients with hypertension, type } \\
2 \text { diabetes of coronary heart disease; } \\
44 \% \text { men in control group, } 52 \% \text { men } \\
\text { in intervention group1, } 51 \% \text { men in } \\
\text { intervention group } 2 \text {; aged between } \\
20 \text { and } 74 \text { years }\end{array}$ & $\begin{array}{l}\text { PNs and GPPs from } 7 \\
\text { practices }\end{array}$ & $\begin{array}{l}\text { (1) Low level: one individual face-to- } \\
\text { face counseling session and monthlyly } \\
\text { telephone contacts for a year (10- } \\
15 \text { min), (2) high level: individual } \\
\text { face-to-face counseling up to } 1 \mathrm{~h} \\
\text { monthly for } 1 \text { year. Counseling was } \\
\text { bered }\end{array}$ & Usual care by GPP & $\begin{array}{l}\text { Nutrition, weight, } \\
\text { physical activity, } \\
\text { alcohol, smoking }\end{array}$ & $\begin{array}{l}\text { Primary and } \\
\text { secondary } \\
\text { prevention }\end{array}$ \\
\hline - & $\begin{array}{l}\text { Woollard et al. } \\
\text { [93]; Australia; } \\
\text { lower quality: RCr }\end{array}$ & See Woollard et al. [93] & $\begin{array}{l}\text { See Woollard et al. } \\
\text { [93] }\end{array}$ & See Woollard et al. [93] & $\begin{array}{l}\text { See Woollard et al. } \\
\text { [93] }\end{array}$ & $\begin{array}{l}\text { See Woollard et al. } \\
\text { [93] }\end{array}$ & $\begin{array}{l}\text { See Woollard et al. } \\
\text { [93] }\end{array}$ \\
\hline
\end{tabular}


Noordman, J., Weijden, T. van der, Dulmen, S. van. Communication-related behavior change techniques used in face-to-face lifestyle interventions in primary care: a systematic review of the literature. Patient Education and Counseling: 2012, 89(2), 227-244

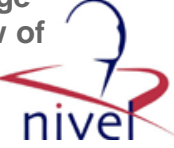

Table 2

Effects of communication related behavior change techniques in studies $(n-50){ }^{2}$

\begin{tabular}{|c|c|c|c|}
\hline $\begin{array}{l}\text { Communication-related behavior change } \\
\text { techniques (used in interventions) }\end{array}$ & Number of studies & $\begin{array}{l}\text { Positive significant } \\
\text { effects }(\%)^{\mathrm{b} .}\end{array}$ & $\begin{array}{l}\text { Contribution GPs (or physidans), nurses, } \\
\text { other health care provider }\end{array}$ \\
\hline Advice, behavioral counseling & $\begin{array}{l}3 \text { High quality studies } \\
{[37,55,56,68]}\end{array}$ & $66.7 \%$ & $\begin{array}{l}1 \text { Study: GPs and health educator }[68]^{*} \text {, } \\
2 \text { Studies: GPs and nurses }[37,55,56]^{*}\end{array}$ \\
\hline Advice, behavioral counseling, self-monitoring & 1 High quality study [73] & - & 1 Study: GPs, dietician, weight loss advisor [73] \\
\hline Advice, education & $\begin{array}{l}3 \text { High quality studies }[50,52,66] \text {, } \\
2 \text { Lower quality studies }[84,91]\end{array}$ & $50 \%$ & 1 Study: nurses [52], 4 studies: GPs $[66,91,50,84]$ \\
\hline Advice, education, cognitive behavior therapy & 1 High quality study [52] & $100 \%$ & 1 Study: nurses and therapists [52] ${ }^{*}$ \\
\hline Advice, education, feedback & 1 High quality study [44] & $100 \%$ & 1 Study: GPs $[44]^{*}$ \\
\hline Advice, education, feedback, goal setting & 1 High quality study [77-79] & $100 \%$ & 1 Study: nurses $[77-79]^{*}$ \\
\hline Advice, education, goal setting, self-monitoring & 1 High quality study [43] & $100 \%$ & 1 Study: GP and nurses [43] \\
\hline Behavioral counseling/support & $\begin{array}{l}10 \text { High quality studies } \\
{[41,46,49,51,53,63,65,72,90,92] \text {, }} \\
3 \text { Lower quality studies } \\
{[62,69,80,81,89]}\end{array}$ & $76.9 \%$ & $\begin{array}{l}6 \text { Studies: nurses }[46,62,63,80,81,90]^{*}[53,89] \\
1 \text { Study: GPS and trained professionals }[72]^{*} \text {, } \\
1 \text { Study: GPs and dieticians }[92]^{*}, 1 \text { Study: } \\
\text { GPS and PA counselors }[51]^{*}, 3 \text { studies: } \\
\text { GPS }[49,69]^{*}[65], 1 \text { study: GPS and nurses [41] }\end{array}$ \\
\hline Behavioral counseling, education & 1 Lower quality study [48] & $100 \%$ & 1 Study: GPS and nurses [48] \\
\hline Behavioral counseling, feedback & 1 Lower quality study [64] & \pm & 1 Study: nurses [64] \\
\hline Behavioral counseling, motivational interviewing & 1 High quality study [67] & \pm & 1 Study: GPS [67] \\
\hline $\begin{array}{l}\text { Education, motivational dialog/interviewing. } \\
\text { behavioral counseling }\end{array}$ & $\begin{array}{l}2 \text { High quality studies }[47,54] \text {, } \\
1 \text { Lower quality study }[74]\end{array}$ & $66.7 \%$ & $\begin{array}{l}1 \text { Study: } 1 \text { nurse [54]", } 1 \text { study: GPs and } \\
\text { nurses [47], } 1 \text { study: nurses and nutritionist [74] }\end{array}$ \\
\hline $\begin{array}{l}\text { Feedback, responsibility, advice, menu, } \\
\text { empathy, self-efficacy }\end{array}$ & 2 High quality studies $[57,59]$ & - & 1 Study: GPS and nurses [57], 1 study: GPS [59] \\
\hline $\begin{array}{l}\text { Goal setting, self-monitoring, motivational } \\
\text { interviewing }\end{array}$ & 1 High quality study [42] & - & 1 Study: GPs and exercise scientist [42] \\
\hline Monitoring, feedback & 1 High quality study [76] & - & 1 Study: GPS [76] \\
\hline Motivational interviewing & $\begin{array}{l}5 \text { High quality studies } \\
\text { [39,40,45,70,71,88]. } \\
3 \text { Lower quality studies }[58,60,93,94]\end{array}$ & $75 \%$ & $\begin{array}{l}3 \text { Studies: nurses }[39,58,45]^{\circ}, 4 \text { studies: } \\
\text { GPS and nurses }[40,60,70,71,93,94]^{*} \text {, } \\
1 \text { Study: GPS }[88]^{*}\end{array}$ \\
\hline Motivational message & 1 High quality study [61] & \pm & 1 Study: GPs [61] \\
\hline Patient-centered care & 1 High quality study [82] & - & 1 Study: GPS and nurses [82] \\
\hline Patient-centered care, advice, education & 1 Lower quality study [91] & $100 \%$ & 1 Study: GPS [91] \\
\hline $\begin{array}{l}\text { Risk/need assessment (screening). } \\
\text { behavior al counseling }\end{array}$ & $\begin{array}{l}1 \text { High quality study [83], } \\
2 \text { Lower quality studies }[75,86]\end{array}$ & $33.3 \%$ & $\begin{array}{l}1 \text { Study: GPs and case managers [83], } \\
1 \text { Study: GPs and nurses (and some dietician, } \\
\text { physiotherapist) [75], } 1 \text { study: GPs [86] }\end{array}$ \\
\hline $\begin{array}{l}\text { Risk assessment, risk communication, } \\
\text { decision support, motivational interviewing }\end{array}$ & 1 High quality study $[38,87]$ & - & 1 Study: nurses $[38,87]$ \\
\hline Self-monitoring, feedback & 1 High quality study [85] & \pm & 1 Study: GPS and nurses [85] \\
\hline
\end{tabular}

- , not significant; \pm , partly significant.

2 Number of studies in table exceeds 50 because several studies reported more than one intervention group which resulted in different behavior change techniques (BCTs) within one study.

${ }^{b}$ Percentage of studies with significant improvement divided by total number of studies on this technique, as earlier used in a review of Van Achterberg et al. [26].

c If in both intervention and control group the same BCT (for example motivational interviewing) was used, but in different intensity or form of delivery, and there was a significant effect in both groups but not between groups, we indicated that there was a significant effect for this BCT. But, if a BCT was partly significant we did not count this effect as significant.

- Significant contribution of health care provider (in case of significant effect on BCT). 
Noordman, J., Weijden, T. van der, Dulmen, S. van. Communication-related behavior change techniques used in face-to-face lifestyle interventions in primary care: a systematic review of the literature. Patient Education and Counseling: 2012, 89(2), 227-244

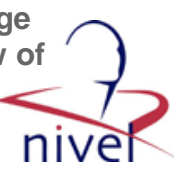

Table 3

Outcome measures and significant effects of studies with effective communication related behavior change techniques $(n-26)$.

\begin{tabular}{ll}
\hline Study & Outcome measures \\
\hline Alterman et al. [52] & $\begin{array}{l}\text { Self-reported: cigarettes a day. } \\
\text { Objective: biochemical measurements (carbon monoxide } \\
\text { level and urine samples) } \\
\text { Self-reported: stress, body function, self-efficacy, phys } \\
\text { activity recall, social support }\end{array}$ \\
Bnderson et al. [68] & $\begin{array}{l}\text { Self-reported: alcohol use (drinks a day), symptoms of } \\
\text { alcohol withdrawal or treatment for alchol problems. } \\
\text { Objective: gamma-glutamyltransferase (GGT) blood te } \\
\text { Belf-reported: fat intake, fiber intake, calories intake, } \\
\text { physical activity level. } \\
\text { Objective: weight, waist circumference, body mass ind } \\
\text { (BMI), diastolic blood pressure, fasting glucose, } \\
\text { triglycerides, hs-CRP, and uric acid values }\end{array}$ \\
Bolognesi et al. [69] & $\begin{array}{l}\text { Self-reported: readiness for physical activity and self- } \\
\text { efficacy. } \\
\text { Objective: BMl and abdominal girth }\end{array}$
\end{tabular}

Campbell et al. [77] Self-reported: aspirin use, diet, smoking, exercise. Objective: blood pressure, lipid management

Efraimsson et al. [54] Self-reported: smoking, symptoms of cough, phlegm, dyspnea and wheezing, quality of life,

Objective: respiratory function, oxygen saturation

Elley et al. [70] Self-reported: quality of live, physical activity level and total energy.

Objective: blood pressure, BMI, cholesterol concentration, risk at cardiovascular disease

Grandes et al. [43] Self-reported: physical activity level, quality of life. Objective: maximum oxygen uptake, estimated by an exercise test

Hollis et al. [37] Self-reported: smoking (quit) rates, stage of change. Objective: carbon monoxide level

Kastarinen et al. [90] Self-reported: lifestyle data on nutrition, physical activity, smoking, alcohol.

Objective: lipids, blood pressure, BMI

Kerse et al. [44]

Self-reported: physical activity level, functional status, heal th, immunization status, social contacts, psychological well-being, drug usage, rate of influenza vaccination

Lear et al. [83] Self-reported: lifestyle (physical activity, nutrition, smoking), cardiovascular risk scores (Framingham), quality

of life.
Objective: blood pressure, cholesterol, exercise capacity. BMI, waist circumference, lipid

Lee et al. [46] Self-reported: self-efficacy, walking frequency.

Objective: systolic and diastolic blood pressure

Noknoy et al. [39] Self-reported: alcohol consumption.

Objective: serum gamma-glutamyl transferase

Pritchard et al. [92] Objective: weight, blood pressure, BMl, height

Ramos et al. [40]

Self-reported: continued smoking abstinence. Objective: carbon monoxide

Rubak et al. [88]

Self-reported: patient-doctor relationship, type of counseling, degree to which behavior tends to be selfdetermined, beliefs and understanding of type 2 diabetes, self-care activities related to type 2 diabetes

Rubio et al. [41]

Self-reported: frequency of binge drinking episodes and weekly alcohol intake.

Objective: gamma-glutamyl transferase

Significant effects

High biochemically abstinence rates through one year for groups 1 and 3 . Significant lower abstinence rates for group 2 .

Reduction in daily stress and improvement in satisfaction with body function for woman in groups 2 and 3. For men reduction of stress in all groups.

Changes in barriers self-efficacy significantly assodated with stress reduction Significant decrease in GGT and average number of drinks a day for treatment group. Control group a smaller reduction in number of drinks a day.

Intervention significantly reduced total/saturated fat intake and increased polyunsaturated fat/fiber intake and exercise level compared to the controls Intervention group: reduced meta bolic syndrome, absolute risk reduction, the prevalence of central obesity, hypertriglyceridemia, incidence of diabetes. Weight, waist circumference, BMI, diastolic blood pressure, fasting glucose, triglycerides, hs-CRP, and uric add values decreased in intervention group, while most variables worsened in the controls.

The experimental group had significantly better BMI and abdominal girth compared with the control group after a 5- to 6-month follow-up. The experimental group progressed in their stage of physical activity readiness and increased their self-efficacy.

Reduced mortality, coronary event rated in medium term. Improved moderate exercise, diet, aspirin management, blood pressure, lipid management in intervention group at one year.

Increase in the intervention group on quality of life, the number of patients who stopped smoking and patients' knowledge about COPD, compared to control

Mean total energy expenditure increased and leisure exercise more in the intervention group than in the control group. Measures of self rated general health, role physical, vitality, and bodily pain improved sign more in the intervention group

Intervention patients increased physical activity more than controls. The proportion of the population achieving minimal physical activity recommendations was higher in the intervention group Subjects in the three intervention conditions were more likely to report a serious quit attempt than control group. Quit rates at 3 months were also higher.

Among participants with no antihypertensive drug treatment, the net reductions after 1 and 2 year in blood pressure were significant in favor of the intervention group. Weight decreased and physical activity level increased at 12,24 months in intervention group compared to control. Alcohol decreased only in year 1.

Patients in the intervention group had increased walking, frequency of pleasurable activities and self-rated health compared with the control group.

Cardiovascular risk score, cholesterol and systolic blood pressure were significantly improved in the intervention group. There were no significant differences with respect to lifestyle factors between the groups

Mean change in systolic blood pressure decreases both in intervention and control group, but significantly more in intervention group. Improvement in exercise self-efficacy scores was greater among intervention group participants. Intervention group participants were more likely to report walking more, but no differences were observed in diastolic blood pressure. Self-reported drinks per drinking day, frequency of hazardous drinking assessed either on a daily or weekly basis, and of binge drinking sessions were reduced in the intervention group more than in the control group after both 3 and 6 months. However, serum gamma-glutamyl transferase increased in both groups

Both intervention groups reduced weight and blood pressure compared with the control group. Patients in intervention group 2 (doctor-dietician) were more likely to complete the 12 month programme than those in intervention group 1 (dietitian)

No significant differences between the results of individual and group interventions. Continued abstinence at 12 months highest for intensive individual intervention group. The effectiveness of intensive smoking interventions was lower than expected; only overall visit length showed a statistically significant assodiation with smoking cessation Patients in the intervention group were significantly more autonomous and motivated in their inclination to change behavior after 1 year compared to the control group. Patients in the intervention group were also significantly more conscious of the importance of controlling their diabetes, and had a significant better understanding of the possibility of preventing complications At 12 -months significant reductions in binge-drinking status, number of episodes of binge drinking, number of drinks weekly and frequency of excessive alcohol intake in 7 days 
Noordman, J., Weijden, T. van der, Dulmen, S. van. Communication-related behavior change techniques used in face-to-face lifestyle interventions in primary care: a systematic review of the literature. Patient Education and Counseling: 2012, 89(2), 227-244

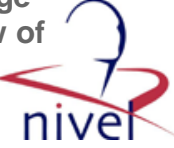

Table 3 (Continued)

\begin{tabular}{|c|c|c|}
\hline Study & Outcome measures & Significant effects \\
\hline Sacerdote et al. [66] & $\begin{array}{l}\text { Self-reported: food frequency, healthy diet score. } \\
\text { objective: weight, blood pressure, BMI }\end{array}$ & $\begin{array}{l}\text { The intervention group showed a slightly reduced net intake of meat and a } \\
\text { slightly increased net intake of fruits and vegetables, fish products, and olive } \\
\text { oil. BMl changed only in the intervention group. The 'healthy diet score' in } \\
\text { intervention group was significant higher in the end, and also compared to } \\
\text { control group. }\end{array}$ \\
\hline Schaus et al. [60] & $\begin{array}{l}\text { Self-reported: alcohol consumption, high-risk drinking } \\
\text { alcohol-related harms. } \\
\text { Objective: blood alcohol concentration }\end{array}$ & $\begin{array}{l}\text { Brief interventions results in significantly decreased al cohol consumption, } \\
\text { high-risk drinking, and alcohol-related harms. }\end{array}$ \\
\hline Spink et al. [49] & $\begin{array}{l}\text { Self-reported: physical activity readiness (stages of } \\
\text { change), levels of physical activity (frequency, intensity. } \\
\text { duration), energy expenditure }\end{array}$ & $\begin{array}{l}\text { Mean energy expenditure and frequency, frequency of moderate activity, and } \\
\text { duration significantly increased over time. No significant interactions between } \\
\text { group and time were found. The effectiveness of telephone support over and } \\
\text { above that of physician counseling was not supported. }\end{array}$ \\
\hline Steptoe et al. [80] & $\begin{array}{l}\text { Self-reported: diet, exercise, smoking habits. } \\
\text { Objective: blood pressure, serum total cholesterol } \\
\text { concentration, weight, BMI, and smoking cessation (with } \\
\text { biochemical validation) }\end{array}$ & $\begin{array}{l}\text { Favorable differences were recorded in the intervention group for dietary fat } \\
\text { intake, regular exercise, and cigarettes smoked per day at } 4 \text { and } 12 \text { months. } \\
\text { Systolic blood pressure was reduced to a greater extent in the intervention } \\
\text { group at } 4 \text { but not at } 12 \text { months. No differences were found between groups in } \\
\text { changes in total serum cholesterol concentration, weight, body mass index, } \\
\text { diastolic pressure, or smoking cessation. }\end{array}$ \\
\hline Steptoe et al. [63] & $\begin{array}{l}\text { Self-reported: number of portions of fruit and vegetables } \\
\text { eaten per day. } \\
\text { Objective: plasma beta carotene, alpha tocopherol, and } \\
\text { ascorbic acid concentrations, and } 24 \mathrm{~h} \text { urinary potassium } \\
\text { excretion. }\end{array}$ & $\begin{array}{l}\text { Consumption of fruit and vegetables increased from baseline to } 12 \text { months in } \\
\text { both intervention groups. The proportion of participants eating five or more } \\
\text { portions a day increased. Plasma beta carotene and alpha tocopherol } \\
\text { concentrations increased in both groups, but the rise in beta carotene was } \\
\text { greater in the behavioral group. There were no changes in plasma ascorbic acid } \\
\text { concentrations or urinary potassium excretion. Differences were maintained } \\
\text { when analysis was restricted to participants with incomes } \leq \mathrm{f} 400 \text { ( } € 596 \text {, } \\
\$ 640 \text { ) a week }\end{array}$ \\
\hline Van Sluis et al. [51] & $\begin{array}{l}\text { Self-reported: self-efficacy, benefits of physical activity. } \\
\text { barriers to physical activity (smoking), social support, } \\
\text { processes of change }\end{array}$ & $\begin{array}{l}\text { Significant positive effect was observed on self-efficacy, use of cognitive and } \\
\text { behavioral processes of change, at } 8 \text { weeks and } 6 \text { months. The intervention } \\
\text { groupalso perceived fewer barriers for regular physical activity at } 6 \text { weeks and } \\
\text { used behavioral processes of change more at } 1 \text { year. }\end{array}$ \\
\hline Whittemore et al. [74] & $\begin{array}{l}\text { Self-reported: nutrition and exercise level, depressive } \\
\text { symptoms, satisfaction. } \\
\text { Objective: weight loss, waist circumference, insulin } \\
\text { resistance, and lipid profiles }\end{array}$ & $\begin{array}{l}\text { Significant trends or improvement in both groups for nutrition and exerdise } \\
\text { behavior. Participants of intervention group demonstrated trends for better } \\
\text { high density lipoprotein (HDL) as well as exercise behavior. Twenty-five } \\
\text { percent of lifestyle participants met treatment goals of } 5 \% \text { weight loss } \\
\text { compared to } 11 \% \text { of standard care participants. }\end{array}$ \\
\hline
\end{tabular}

Table 4

Effective communication related behavior change techniques (BCTs), combined and single ( $n=26$ studies).

\begin{tabular}{|c|c|c|c|c|c|c|c|c|c|}
\hline $\begin{array}{l}\text { Communication-related } \\
\text { BCTs/number of studies }\end{array}$ & $\begin{array}{l}\text { Behavioral } \\
\text { counseling }\end{array}$ & Feedback & $\begin{array}{l}\text { Risk } \\
\text { assessment }\end{array}$ & Education & $\begin{array}{l}\text { Goal } \\
\text { setting }\end{array}$ & Advice & $\begin{array}{l}\text { Self- } \\
\text { monitoring }\end{array}$ & $\begin{array}{l}\text { Motivational } \\
\text { interviewing }\end{array}$ & $\begin{array}{l}\text { Cognitive } \\
\text { behavior } \\
\text { therapy }\end{array}$ \\
\hline 1 & & & & $\mathrm{x}$ & & $x$ & & & $x$ \\
\hline 2 & $x$ & & & & & $x$ & & & \\
\hline 1 & & & & $x$ & & $x$ & & & \\
\hline 1 & & & & $\mathrm{x}$ & $x$ & $\mathrm{x}$ & $\mathrm{x}$ & & \\
\hline 1 & & $\mathrm{x}$ & & $x$ & & $x$ & & & \\
\hline 1 & & $\mathrm{x}$ & & $\mathrm{x}$ & $x$ & $x$ & & & \\
\hline 2 & $\mathrm{x}$ & & & $\mathrm{x}$ & & & & $\mathrm{x}$ & \\
\hline 1 & $\mathrm{x}$ & & $x$ & & & & & & \\
\hline 6 & & & & & & & & $x$ & \\
\hline 10 & $\mathrm{x}$ & & & & & & & & \\
\hline Total $^{2}$ & $15 / 26$ & $2 / 7$ & $1 / 4$ & $7 / 14$ & $2 / 3$ & $7 / 16$ & $1 / 6$ & $8 / 14$ & $1 / 1$ \\
\hline
\end{tabular}

\footnotetext{
2 For example; behavioral counseling was 15 times used as effective technique out of a total of 26 times used as technique.
} 